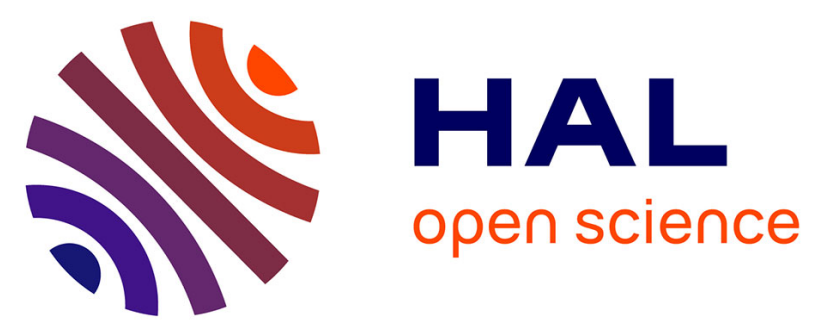

\title{
In vitro cellular responses to silicon carbide particles manufactured through the Acheson process: impact of physico-chemical features on pro-inflammatory and pro-oxidative effects.
}

Delphine Boudard, Valérie Forest, Jérémie Pourchez, Najih Boumahdi, Maura

Tomatis, Bice Fubini, Bernard Guilhot, Michèle Cottier, Philippe Grosseau

\section{To cite this version:}

Delphine Boudard, Valérie Forest, Jérémie Pourchez, Najih Boumahdi, Maura Tomatis, et al.. In vitro cellular responses to silicon carbide particles manufactured through the Acheson process: impact of physico-chemical features on pro-inflammatory and pro-oxidative effects.. Toxicology in Vitro, 2014, 28 (5), pp.856-865. 10.1016/j.tiv.2014.02.012 . hal-01021766

\section{HAL Id: hal-01021766 \\ https://hal.science/hal-01021766}

Submitted on 9 Jul 2014

HAL is a multi-disciplinary open access archive for the deposit and dissemination of scientific research documents, whether they are published or not. The documents may come from teaching and research institutions in France or abroad, or from public or private research centers.
L'archive ouverte pluridisciplinaire HAL, est destinée au dépôt et à la diffusion de documents scientifiques de niveau recherche, publiés ou non, émanant des établissements d'enseignement et de recherche français ou étrangers, des laboratoires publics ou privés. 
In vitro cellular responses to silicon carbide particles manufactured through the Acheson process: impact of physico-chemical features on pro-inflammatory and prooxidative effects.

Delphine Boudard* abc, Valérie Forest ${ }^{\text {bd }}$, Jérémie Pourchez ${ }^{\text {bd }}$, Najih Boumahdi ${ }^{\text {be }}$, Maura Tomatis ${ }^{\mathrm{f}}$, Bice Fubini ${ }^{\mathrm{f}}$, Bernard Guilhot ${ }^{\text {be }}$, Michèle Cottier ${ }^{\text {abc }}$, Philippe Grosseau be

${ }^{a}$ Université Jean Monnet Saint-Etienne, F-42023, Saint-Etienne, France, EA 4624 LINA

${ }^{\mathrm{b}}$ SFR IFRESIS, F-42023, Saint-Etienne, France

${ }^{\mathrm{c}}$ CHU de Saint-Etienne, F-42055, Saint-Etienne, France

${ }^{\mathrm{d}}$ Ecole Nationale Supérieure des Mines, CIS-EMSE, EA 4624 LINA, F-42023 Saint-Etienne, France

${ }^{\text {e }}$ Ecole Nationale Supérieure des Mines, SPIN-EMSE, CNRS: UMR5307, LGF, F-42023 Saint-Etienne, France

f Dipartimento di Chimica and 'G. Scansetti' Interdepartmental Center for Studies on Asbestos and other Toxic Particulates, Università di Torino, Torino, Italy

*Correspondence to: Delphine Boudard, EA 4624 LINA, Université Jean Monnet, Faculté de Médecine, 15 rue Ambroise Paré, F-42023, Saint-Etienne, France. Phone: (+33) 04774214 43, Fax: (+33) 04774214 89, E-mail: delphine.boudard@univ-st-etienne.fr

E-mail addresses: vforest@emse.fr, pourchez@emse.fr, Najih.Boumahdi@saint-gobain.com, m.tomatis@unito.it, bice.fubini@unito.it, guilhot@emse.fr, etienne.fr, grosseau@emse.fr 


\section{Abbreviations}

BET method: Brunauer-Emmet-Teller method

COO־: Carboxyl radical

DMEM: Dulbecco's Modified Eagle's Medium

EPR: Electron Paramagnetic Resonance

FCS: Fetal Calf Serum

$\mathrm{HO}^{\circ}:$ Hydroxyl radical

$\mathrm{H}_{2} \mathrm{O}_{2}$ : Hydrogen peroxide

ICP: Inductively Coupled Plasma spectrometry

ROS: Reactive Oxygen Species

SiC: Silicon carbide

SSA: Specific Surface Area

TNFa: Tumor Necrosis Factor alpha

XPS: X-ray Photoelectron Spectroscopy 


\begin{abstract}
Silicon carbide ( $\mathrm{SiC}$ ) an industrial-scale product manufactured through the Acheson process, is largely employed in various applications. Its toxicity has been poorly investigated. Our study aims at characterizing the physico-chemical features and the in vitro impact on biological activity of five manufactured $\mathrm{SiC}$ powders: two coarse powders ( $\mathrm{SiC} \mathrm{C1/C2}$ ), two fine powders ( $\mathrm{SiC}$ F1/F2) and a powder rich in iron impurities (SiC I). RAW 264.7 macrophages were exposed to the different $\mathrm{SiC}$ particles and the cellular responses were evaluated. Contrary to what happens with silica, no SiC cytotoxicity was observed but prooxidative and pro-inflammatory responses of variable intensity were evidenced. Oxidative stress $\left(\mathrm{H}_{2} \mathrm{O}_{2}\right.$ production) appeared related to $\mathrm{SiC}$ particle size, while iron level regulated proinflammatory response (TNF $\alpha$ production). To investigate the impact of surface reactivity on the biological responses, coarse $\mathrm{SiC} \mathrm{C1}$ and fine $\mathrm{SiC} \mathrm{F1}$ powders were submitted to different thermal treatments $\left(650\right.$ to $\left.1400^{\circ} \mathrm{C}\right)$ in order to alter the oxidation state of the particle surface. At $1400^{\circ} \mathrm{C}$ a decrease in $\mathrm{TNF} \alpha$ production and an increase in $\mathrm{HO}^{\circ}, \mathrm{COO}^{\circ-}$ radicals production were observed in correlation with the formation of a surface layer of crystalline silica. Finally, a strong correlation was observed between surface oxidation state and in vitro toxicity.
\end{abstract}

Keywords: silicon carbide powders, Acheson process, thermal post-treatment, physicochemical characterization, biological toxicity, occupational exposure. 


\section{Introduction}

Silicon carbide (SiC) was discovered in 1892 by Edward Goodrich Acheson who searched a diamond substitute material (Acheson, 1893). Today SiC denomination is a generic term that refers to a family of different materials sharing some common physico-chemical characteristics. The production of $\mathrm{SiC}$, a well known material has significantly increased during the past fifty years mainly due to its remarkable properties such as high chemical inertness, elevated thermal stability and excellent mechanical properties. SiC particles are widely used for many different industrial purposes in the ceramic or composite material field, including particulate filters and abrasives (Pham-Huu et al., 1999).

$\mathrm{SiC}$ is industrially manufactured through the Acheson process. Reactants (petroleum coke and silica) are placed all around a graphite resistance in an electric furnace in order to enable the carbothermal reduction of $\mathrm{SiO}_{2}$ into $\mathrm{SiC}$ at high temperature. At the end of the firing and after several post-process operations (crushing, grinding, etc.) polydisperse $\mathrm{SiC}$ powders are obtained. At each step of this process, aerosolized $\mathrm{SiC}$ fractions as well as by-products, can be generated in the work environment and can potentially be inhaled by the workers. A health risk among SiC workers has been noticed since the beginning of the $19^{\text {th }}$ century (Winslow et al., 1919; Bruusgaard, 1948). Occupational analyses focusing on the Acheson process showed that the airborne environment was charged with $\mathrm{SiC}$ microparticles, $\mathrm{SiC}$ fibers and impurities, especially crystalline silica and carbon (Hayashi and Kajita, 1988; Osterman et al., 1989). Moreover, analyses of lung tissue biopsies from workers exposed to these powders have revealed substantial amounts of $\mathrm{SiC}$ particles in alveolar spaces and interstitial fibrosis associated with an increased pneumoconiosis incidence (Funahashi et al., 1984; Hayashi and Kajita, 1988; Massé et al., 1988; Dufresne et al., 1992). Taken together, these observations were considered to be the result of a silicogenic (fibrogenic) effect (Bruch et al, 1993b) and 
showed the importance of occupational risk evaluation on $\mathrm{SiC}$ exposure, through toxicological studies (Bruch et al., 1993a, 1993b; Bruch and Rehn, 1996).

Toxicological data available in the literature are mainly obtained from experiments conducted on micro-scaled SiC particles or fibers (called whiskers), but SiC toxicity has been poorly investigated and the few reported data are controversial, making it difficult to draw clear conclusions. For instance, it has been shown that $\mathrm{SiC}$ particles do not induce harmful effects on tissues, suggesting that $\mathrm{SiC}$ material is quite biologically inert (Bruch et al., 1993a, 1993b). Conversely, other studies have suggested potential adverse effects induced by SiC. In vivo exposure to whiskers triggers lung inflammation (Cullen et al., 1997), granulomas (Vaughan et al., 1993), bronchoalveolar hyperplasia and severe lung fibrotic changes (Akiyama et al., 2007), while micro-scaled SiC particles were associated to oxidative stress, genotoxic and carcinogenic effects (Cichy, 1989; Svensson et al., 1997; Allen et al., 1995). Moreover, in vitro responses are characterized by significant reactive oxygen species (ROS) generation (Svensson et al., 1997), cytotoxic and genotoxic effects (Svensson et al., 1997; Allen et al., 1995), and stimulation of pro-inflammatory cytokines production like TNF $\alpha$ (Allen et al., 1995; Cullen et al., 1997). These results mainly underline a potential impact of SiC particle shape on the biological activity, because $\mathrm{SiC}$ whiskers (i.e. long and rigid rods of $\mathrm{SiC}$ ) induce more important biological activity than isotropic SiC particles (Svensson et al., 1997).

Recent in vitro studies, specifically devoted to SiC nanoparticles, highlighted an accumulation of particles in A549 lung epithelial cells, a major cell oxidation-reduction status disturbance and DNA damage (Barillet et al., 2010a; Barillet et al., 2010b). Another study clearly showed the impact of the nanoparticle surface area and the nature of crystalline phases $(\alpha-\operatorname{SiC} v s . \beta-$ $\mathrm{SiC}$ ) on the TNF $\alpha$ production, the influence of the iron content at the nanoparticle surface on the free radical release, and the surface oxidation on the cellular $\mathrm{H}_{2} \mathrm{O}_{2}$ production (Pourchez et al., 2012). Thus, these authors proposed to reconsider SiC nanoparticles biocompatibility 
and to handle $\mathrm{SiC}$ nanoparticles with caution until more toxicological information is available.

In this context, it seems crucial to investigate more deeply the interactions between $\mathrm{SiC}$ industrial powders manufactured through the Acheson process and living cells. Consequently, we conducted a multidisciplinary study in order to examine the impact of the physicochemical parameters of $\mathrm{SiC}$ industrial particles on the in vitro cellular responses. As a matter of fact, a main challenge is the lack of comprehensive data to assess the potential toxicity of a SiC industrial particle collection regarding different sizes, oxidation state of surfaces, crystallographic structure or chemical composition. These complementary physico-chemical and biological approaches may be particularly suitable for a safer by design development.

To reach this objective we studied 5 polydisperse $\mathrm{SiC}$ powders manufactured by the Acheson process in industrial plants: two coarse $\mathrm{SiC} \mathrm{C1/C2}$ powders; two fine $\mathrm{SiC} F 1 / \mathrm{F} 2$ powders and a coarse impure powder SiC I with a high level of metallic impurities. Their physico-chemical features were first characterized: crystallographic structure, $\mathrm{C} / \mathrm{Si}$ atomic ratio (i.e. silicon or carbon excess), surface oxidation state (i.e. the formation of a silica or oxycarbide layer around the $\mathrm{SiC}$ grain) and the presence of iron impurities on particle surface. In vitro toxicological assessment was then carried out using macrophages (RAW 264.7, a cultured murine macrophage cell line widely used in toxicological studies due to its phagocytic capacity). The cytotoxicity (LDH release), a pro-inflammatory effect (TNF $\alpha$ production), and the oxidative stress $\left(\mathrm{H}_{2} \mathrm{O}_{2}\right.$ specific production) were assessed. Finally, the particle potential to release free radical species was evaluated in cell free condition. Two radical-generating mechanisms have been examined: i) $\mathrm{HO}^{\bullet}$ radical generation in the presence of hydrogen peroxide. This test mimics the contact with lysosomal fluids where $\mathrm{H}_{2} \mathrm{O}_{2}$ is released following particle phagocytosis by alveolar macrophages; and ii) $\mathrm{COO}^{*-}$ from the formate ion, used as a 
model target molecule for homolytic cleavage of a carbon-hydrogen bond in several organic molecules and biomolecules.

Finally, to better investigate the impact of the surface nature of the particles on cellular responses, coarse $\mathrm{SiC} \mathrm{C} 1$ and fine $\mathrm{SiC} F 1$ powders underwent an oxidative thermal posttreatment at different temperatures $\left(650^{\circ} \mathrm{C}, 750^{\circ} \mathrm{C}, 850^{\circ} \mathrm{C}, 1400^{\circ} \mathrm{C}\right)$. Biological activity was then assessed.

\section{Materials and methods}

\section{Collection of manufactured SiC powders}

In this study, the $5 \mathrm{SiC}$ industrial powders used ( $\mathrm{SiC} \mathrm{C} 1 / \mathrm{C} 2 / \mathrm{F} 1 / \mathrm{F} 2$ and $\mathrm{I})$ were produced by the Acheson process, and collected in industrial plants. SiC C1 and C2 particles correspond to coarse $\alpha-\mathrm{SiC}$ microparticles and are mainly used for abrasives and refractory applications. SiC F1 and F2 particles correspond to fine $\alpha$-SiC microparticles and are mainly used for particulate filters and technical ceramics. SiC I powder can be considered as a metallurgical impure powder with no particular industrial application, but this sample is representative of airborne dusts that can be disseminated and inhaled in the workplace environment. Only alveolar fractions of $\mathrm{SiC}$ powders have been studied using a vertical elutriator (Boumahdi, 2009). This fraction corresponds to particles lower than $10 \mu \mathrm{m}$ contained in raw powders.

\section{Oxidative thermal post-treatment}

SiC $\mathrm{C} 1$ and $\mathrm{F} 1$ powders were submitted to increasing thermal treatments under air atmosphere. SiC grains monolayer bed was laid out in a crucible (AluSIK-99 ZA) in the middle of a tubular furnace (Nabertherm RHT08/17), and exposed for 2 hours at the following temperatures: $650^{\circ} \mathrm{C}, 750^{\circ} \mathrm{C}, 850^{\circ} \mathrm{C}$ and $1400^{\circ} \mathrm{C}$. 


\section{SiC particles characterization}

SiC physico-chemical characteristics were investigated using the following methods. Particles morphology was observed using a field-emission scanning electron microscope (JEOL JSM$6500 \mathrm{~F})$. The specific surface area (SSA, $\mathrm{m}^{2} / \mathrm{g}$ ) was determined by $\mathrm{N}_{2}$ adsorption at $77 \mathrm{~K}$ after out-gassing $2 \mathrm{~h}$ at $200^{\circ} \mathrm{C}$ (Micromeritics ASAP 2000), using the Brunauer-Emmet-Teller (BET) method. Particle size distribution and crystalline structure were determined respectively by laser granulometry (Malvern, Mastersizer 2000) and X-ray diffractometry with a semi-quantitative analysis by Rietveld Method (Siemens Kristalloflex diffractometer D8). Particle median diameter $\mathrm{D}_{50}(\mathrm{BET}$ size,$\mu \mathrm{m})$ was calculated as BET size $=6000 /(\rho \times$ SSA). Concentration of constitutive elements ( $\mathrm{Si}, \mathrm{C})$ and impurities (especially iron and aluminum) was deduced from elemental chemical analysis by inductively coupled plasma spectrometry (ICP, Jobin-Yvon Activa). The oxidation state of SiC powders (silica, quartz, cristobalite, oxycarbide layer around $\mathrm{SiC}$ grains) was characterized by surface analysis using X-ray photoelectron spectroscopy (XPS, Thermo VG Thetaprobe) and X-ray diffractometry.

\section{Free radical release in cell free system}

Electron paramagnetic resonance (EPR) using the spin-trapping technique (Fubini et al., 1995b) was used to evaluate $\mathrm{SiC}$ particle potential to generate free radicals (hydroxyl radical $\mathrm{HO}^{\circ}$, carboxyl radical $\left.\mathrm{COO}^{\circ}\right)$ in aqueous suspensions. Each powder $(45 \mathrm{mg})$ was suspended in a buffered solution (0.5M potassium phosphate buffer, $\mathrm{pH} 7.4) 0.15 \mathrm{M}$ of DMPO (5-5'dimethyl-1-pirroline-Noxide). The reaction was started by adding the substrate molecule respectively hydrogen peroxide $(1.0 \mathrm{M})$ or sodium formate $(1.0 \mathrm{M})$ to the $\mathrm{SiC}$ particle suspension. The radical yield was progressively measured in a $50 \mu \mathrm{l}$ aliquot of the suspension up to one hour. Radical species release was monitored in the suspension by EPR spectroscopy (Miniscope 100 EPR spectrometer, Magnettech). The instrument settings were as follows: 
microwave power $10 \mathrm{~mW}$; modulation $1000 \mathrm{mG}$; scan range $120 \mathrm{G}$; centre of field approximately $3345 \mathrm{G}$. The use of internal standard (Mn) enabled radical activity quantification. Each experiment was repeated independently three times for each powder and included controls: amorphous silica (radical negative control) and DQ12 quartz (toxicological positive control)(Bruch et al., 2004; Fubini et al., 2004).

\section{Cell line and culture conditions}

The RAW 264.7 cell line derived from murine peritoneal macrophages transformed by the AML Virus (Abelson Murine Leukemia Virus) was provided by the ATCC Cell Biology Collection (Promochem LGC, Molsheim). Cells were cultured in Dulbecco's Modified Eagle's Medium (DMEM, Invitrogen), complemented with 10\% fetal calf serum (FCS, Invitrogen), $1 \%$ penicillin-streptomycin (penicillin 10000 units $/ \mathrm{mL}$, streptomycin 10mg/mL; SigmaAldrich, Saint-Quentin Fallavier, France) and incubated at $37^{\circ} \mathrm{C}$ under a $5 \%$ carbon dioxide humidified atmosphere.

For each experiment, as described by Leclerc et al. (2010), cells were prepared in 96-well plates (100 000 cells/well for TNF $\alpha$ and LDH assays) in $25 \mu \mathrm{L}$ of complete DMEM (DMEMc). Suspensions of SiC powders were prepared in $75 \mu \mathrm{L}$ of DMEMc which were added to the culture and incubated either for $90 \mathrm{~min}$ or $24 \mathrm{~h}$ at $37^{\circ} \mathrm{C}$ in a $5 \% \mathrm{CO}_{2}$ atmosphere, depending on the biological parameter studied (cytotoxicity, TNF $\alpha$ production or oxidative stress), as described below. Cell viability was determined by trypan blue dye exclusion (FDA, Sigma), after each contact between cells and particles.

Different doses were tested: $15,30,60$ and $120 \mu \mathrm{g}$ of particles per $\mathrm{mL}$ of culture medium. Negative and positive controls of toxicity, corresponding to the cells incubated alone or incubated with DQ12 quartz respectively (Bruch et al., 2004) were included. Three independent experiments were performed for each condition. 


\section{Cytotoxicity assays}

The activity of the lactate dehydrogenase $(\mathrm{LDH})$ released from cells with damaged membranes in the culture supernatant was assessed after a $24 \mathrm{~h}$ incubation of cells with $\mathrm{SiC}$ particles. The CytoTox-ONE ${ }^{\mathrm{TM}}$ Homogeneous Membrane Integrity Assay (Promega, Charbonnières les bains, France) was used according to the manufacturer's instructions. Detection was performed using a fluorometer (Fluoroskan Ascent, Thermolabsystems), with excitation/emission wavelengths set at $530 / 590 \mathrm{~nm}$. The activity of the released LDH was reported to that of total cellular LDH (measured after the lysis of control cells) and was expressed as a percentage of the control.

\section{Pro-inflammatory $T N F \alpha$ production}

Tumor Necrosis Factor alpha $(\mathrm{TNF} \alpha)$ production was assessed in the culture supernatant after a 24h incubation of cells with $\mathrm{SiC}$ particles. A commercial ELISA Kit (Quantikine® Mouse TNF $\alpha$ Immunoassay, R\&D Systems, Lille, France) was used according to the manufacturer's instructions. The optical density of each well was determined using a microplate reader (Multiskan RC, Thermolabsystems, Helsinki, Finland) set at $450 \mathrm{~nm}$. A standard curve was established and results were expressed in $\mathrm{pg} / \mathrm{mL}$ of $\mathrm{TNF} \alpha$.

\section{Oxidative stress with $\mathrm{H}_{2} \mathrm{O}_{2}$ production}

Acute oxidative stress was assessed by the production of $\mathrm{H}_{2} \mathrm{O}_{2}$ after 90 min interaction between the cells and the different types of $\mathrm{SiC}$ powders. Hydrogen peroxide $\mathrm{H}_{2} \mathrm{O}_{2}$ production was measured according to the protocol of De la Harpe and Nathan (1985). Briefly, KRPG (Krebs-Ringer phosphate glucose) buffer, containing a mixture of scopoletin $(30 \mu \mathrm{M}), \mathrm{NaN}_{3}$ $(1 \mathrm{mM})$ and horseradish peroxidase (1 unit pupurogallin/ml HPO) was added to cells. Over a $90 \mathrm{~min}$ period, fluorimetric determination $(355 / 460 \mathrm{~nm}$ excitation/emission wavelengths) of 
scopoletin oxidation, catalyzed by horseradish peroxidase was measured (Fluoroskan Multiskan). Results were expressed as the amount of $\mathrm{H}_{2} \mathrm{O}_{2}$ released by cells (nmol $\mathrm{H}_{2} \mathrm{O}_{2} / 10^{6}$ cells).

\section{Statistical analysis}

For the several parameters of in vitro biological evaluation, a statistical analysis was carried out using a two-way analysis ANOVA test with Bonferroni post-test, in order to perform multiple comparisons between the different $\mathrm{SiC}$ particles against the same biological negative control (cells incubated alone, or amorphous silica for free radical $\mathrm{HO}^{\bullet}$ and $\mathrm{COO}^{\circ-}$ release). A one-way ANOVA test with Bonferroni post-test was used to compare the same powder SiC C1 / F1 either native (unoxidized, that serves as a control) or submitted to various temperatures. Analysis and graphics were performed on Prism 5.0 software (GraphPad, San Diego, CA). Only points with a test significance at $\mathrm{p}<0.001(* * *)$ were reported into the graphs. Results are expressed as means of three independent experiments.

A linear regression curve with the $\mathrm{R}^{2}$ coefficient was also established for the $\mathrm{H}_{2} \mathrm{O}_{2}$ production depending on the SiC particle surface $\left(\mathrm{cm}^{2}\right)$, after adding a trendline to excel data base.

\section{Results and discussion}

A comprehensive physico-chemical characterization of 5 industrial SiC powders was carried out, followed by the in vitro evaluation of the biological responses.

Physico-chemical data are presented in Table 1 with an illustration of the morphological aspect of $\mathrm{SiC}$ particles given by Figure 1 . SiC powders were polydispersed and exhibited an irregular-shaped morphology characterized by a smooth surface with sharp ridges and the presence of submicronic particles fixed on larger particles which is a common feature of powders synthesized by the Acheson process (Figure 1). 
They could be classified either as $2.5 \mu \mathrm{m}$ coarse particles ( $\mathrm{SiC} \mathrm{C1}$ and $\mathrm{C} 2$ ) or $0.5 \mu \mathrm{m}$ fine particles (SiC F1 and F2). SiC I was kept apart because of a higher size (6 $\mu \mathrm{m})$, the presence of crystallized silica and its very high metallic impurities content (iron about 20000 ppm compared to $2500 \mathrm{ppm}$ for other powders). Except SiC I showing a very high crystallized silica content and only $65 \%$ of $\alpha$-SiC phases, the other SiC powders correspond to pure $\alpha$-SiC phases (> 99\%), with very similar features in terms of $\mathrm{C} / \mathrm{Si}$ ratio around 1 and crystallographic structure (principally with $\mathrm{SiC}-6 \mathrm{H}$ polytype and $\mathrm{SiC}-4 \mathrm{H}$ and $\mathrm{SiC}-15 \mathrm{R}$ $<10 \%)$. By contrast $\mathrm{SiC}$ I powder has a $1.66 \mathrm{C} / \mathrm{Si}$ ratio associated with high oxygen and free carbon levels $\left(\% \mathrm{O} \approx 6 \%, \% \mathrm{C}_{\text {Free }} \approx 17.5 \%\right)$ and the presence of crystallized silica $(9 \%$ of quartz and $5 \%$ of cristobalite).

Biological effects of SiC powders concerning cytotoxicity, pro-inflammatory $\mathrm{TNF} \alpha$ response and oxidative stress are reported in Figures 2, 3 and 4 respectively.

Surprisingly all the $5 \mathrm{SiC}$ powders manufactured through the Acheson process were found to be globally not cytotoxic (Figure 2), contrary to nano-sized SiC particles synthetized by other routes as shown by Pourchez et al. (Pourchez et al, 2012). Only the positive control (DQ12 quartz) clearly showed a significantly enhanced and dose-dependent LDH release.

All particles induced a moderate pro-inflammatory response (Figure 3), except $\mathrm{SiC}$ I which generated a strong TNF $\alpha$ production (around $3000 \mathrm{pg} / \mathrm{ml}$ at $120 \mu \mathrm{g}$ dose for example), even higher than that induced by the DQ12 quartz (around $2400 \mathrm{pg} / \mathrm{ml}$ at the same dose). This SiC I atypical profile could be explained on the one hand by the presence of crystallized silica (quartz and cristobalite) with high free carbon levels, and on the other hand by its high content of iron impurities (Table 1) (Fubini et al., 1999; Governa et al., 2005; IARC, 1996). It has been well described in the literature that there is a relationship between the presence of surface transition metal ions (especially iron) and cellular responses (Fubini et al., 1995b; Pritchard et al., 1996; Aust et al., 2000), especially for free radical generation (Fubini and 
Hubbard, 2003; Fenoglio et al., 2001; van Maanen et al., 1999; Turci et al., 2011; Pourchez et al., 2012). Indeed iron is known to be a catalyst in the formation of several reactive oxygen species (Pierre and Fontecave, 1999), particularly the hydroxyl radical can be generated through the Fenton reaction $\left(\mathrm{Fe}^{2+}+\mathrm{H}_{2} \mathrm{O}_{2} \rightarrow \mathrm{Fe}^{3+}+\mathrm{OH}^{-}+\mathrm{HO}^{*}\right)$ when ferrous iron $(\mathrm{Fe}[\mathrm{II}])$ are converted into ferric iron (Fe[III]) (Halliwell and Gutteridge, 1992). Oxidative stress is not only the result of an over-production of oxygen reactive species, it also implies that physiological antioxidant defenses are overwhelmed. But this antioxidant aspect will not be evaluated in this study.

$\mathrm{H}_{2} \mathrm{O}_{2}$ cellular production and free radical generation in cell free test have been employed to assess the ability of $\mathrm{SiC}$ particles to induce oxidative stress. $\mathrm{H}_{2} \mathrm{O}_{2}$ production induced by fine $\mathrm{SiC} \mathrm{F1}$ and F2 particles, regardless the dose was much higher than that triggered by the coarse $\mathrm{SiC} \mathrm{C1} / \mathrm{C} 2$ or SiC I powders and even more elevated than that caused by the DQ12 quartz (Figure 4). This suggests that particle size may have a role in some cellular responses, particularly on ROS intracellular generation. A linear relationship is indeed detectable between $\mathrm{H}_{2} \mathrm{O}_{2}$ production and the SSA parameter $\left(\mathrm{y}=15.9 \mathrm{x}+21.5\right.$, where $\mathrm{y}=\mathrm{H}_{2} \mathrm{O}_{2}$ production in $\mathrm{nmol} / 10^{6}$ cells and $\mathrm{x}=$ particle surface in $\mathrm{cm}^{2} ; \mathrm{R}^{2}=0.9$, supplementary Figure 1). This is in agreement with a previous study which has shown a significant impact of nanosized SiC specific surface area on in vitro cellular responses (Pourchez et al., 2012) and also with results previously published in the literature for other particles like $\mathrm{TiO}_{2}$ and carbon black (Oberdörster et al., 1994; Oberdorster, 2000; Oberdörster et al., 2005; Brown et al., 2001; Höhr et al., 2002; Donaldson et al., 2002; Fubini, 2007).

To investigate the ability of $\mathrm{SiC}$ to generate particle-derived free radicals (not at the cellular level), $\mathrm{HO}^{\bullet}$ and $\mathrm{COO}^{\circ-}$ production was assessed in cell free condition by EPR spectroscopy (Figure 5). All particles were able to release free radicals and were more effective in COO*than in $\mathrm{HO}^{\bullet}$ radical generation. Free radical production increased with particle size, it was 3-5 
folds higher for the coarse $\mathrm{SiC} \mathrm{C1/C2}$ particles than for fine $\mathrm{SiC}$ F1/F2 particles (maximal $\mathrm{COO}^{*-}$ production for $\mathrm{SiC} \mathrm{C} 2$ ). The $\mathrm{SiC}$ I powder was characterized rather by a $\mathrm{HO}^{\bullet}$ radical profile, with a 5-fold production compared to $\mathrm{SiC} \mathrm{F1/F2.} \mathrm{This} \mathrm{behavior} \mathrm{may} \mathrm{be} \mathrm{related} \mathrm{to} \mathrm{the}$ large amount of iron (Table 1) in the coarse particles if compared to the fine ones, especially SiC I which exhibited also a partially crystallized surface silica layer. Note that $\mathrm{HO}^{\bullet}$ and $\mathrm{COO}^{*-}$ release did not parallel the $\mathrm{H}_{2} \mathrm{O}_{2}$ production observed in macrophage cells (Figure 4), since these tests reflect different outcomes and depend upon different parameters. $\mathrm{H}_{2} \mathrm{O}_{2}$ production in cellular test reflects macrophage activation, following particle phagocytosis. This is a complex process initiated by the interaction between the particle and the phagocyte, which may be affected by several physico-chemical features of the particle itself (size, shape, surface charge, hydrophilicity etc.). Conversely, free radical generation in cell free medium only depends on the intrinsic characteristics of the particle surface, e.g. presence of reactive sites (e.g. redox active metal ions) or crystalline state. Once inhaled, the particle is in contact with several organic molecules such as proteins, non enzymatic antioxidants, lipids. Carboxyl radical release reflects the potential of inhaled particles to react with these molecules promoting the cleavage of $\mathrm{C}-\mathrm{H}$ bonds. This mechanism may take place in extracellular fluids before macrophage phagocytosis. Opposite to $\mathrm{C}-\mathrm{H}$ cleavage, $\mathrm{HO}^{\bullet}$ release only occurs in $\mathrm{H}_{2} \mathrm{O}_{2}$ rich-fluids such as phagolysosomal fluid, and reflects the ability of inhaled particle to react with $\mathrm{H}_{2} \mathrm{O}_{2}$. We therefore expect a consumption of $\mathrm{H}_{2} \mathrm{O}_{2}$ following Fenton or Fenton-like reactions.

To investigate the role of surface oxidation state, two SiC powders (C1 and F1) were submitted to increasing thermal treatments (from 600 to $1400^{\circ} \mathrm{C}$ ). Oxidative thermal treatments led to surface modifications characterized by an increase of the silica layer thickness at $1400^{\circ} \mathrm{C}$, as illustrated in Figure 6 (Deal and Grove, 1965; Filipuzzi, 1991; Shi et al., 2001; Das et al., 2004). At this temperature $\mathrm{Fe}^{2+}$ is also converted into $\mathrm{Fe}^{3+}$. 
The physico-chemical characterization of the oxidized $\mathrm{SiC} \mathrm{C1}$ and $\mathrm{SiC}$ F1 powders revealed no significant changes in the morphology or specific surface area of the particles, except at $1400^{\circ} \mathrm{C}$ where the morphology was strongly modified presenting a grain aspect mainly characterized by less sharp ridges and more rounded edges. SiC particles were progressively covered with a surface amorphous $\mathrm{SiO}_{2}$ layer which was transformed into cristobalite silica at $1400^{\circ} \mathrm{C}$ (Table 2 and Figure 6). This observation was correlated with an increased oxide layer, judging by the silica evolution and a silicon carbide peak decrement (data not shown). At $1400^{\circ} \mathrm{C}$, oxidized $\mathrm{SiC} \mathrm{C} 1$ and $\mathrm{SiC}$ F1 showed both a SSA and a $\mathrm{C} / \mathrm{Si}$ ratio decrement (Table 2).

The biological activity assessment after thermal treatments is presented in Figures 7 to 10 . A significant development of cytotoxicity was observed for oxidized SiC F1 compared to that of the original SiC F1 powder, whatever the temperature (Figure 7B), reaching values similar to that of the positive control DQ12. On the contrary, oxidative treatments had a more limited effect on the cytotoxicity of $\mathrm{SiC} \mathrm{C} 1$, except for specific temperatures and dose particles (Figure 7A). At an equivalent dose, the LDH release for the fine oxidized SiC F1 powder was higher than for the coarse oxidized $\mathrm{SiC} \mathrm{C1}$ powder, suggesting that fine particles exhibiting a higher surface could be more easily oxidized, which resulted in a higher cytotoxicity.

Similarly, oxidized SiC C1 showed no significant production of $\mathrm{TNF} \alpha$ compared to the negative control and unoxidized $\mathrm{SiC} \mathrm{C} 1$ whereas oxidized $\mathrm{SiC}$ F1 (from $650-850^{\circ} \mathrm{C}$ ) exhibited a TNF $\alpha$ production drastically higher than that induced by SiC F1 particles (Figure 8A and 8B). However, it is interesting to note that both oxidized $\mathrm{SiC} \mathrm{C1}$ and $\mathrm{SiC} \mathrm{F1}$ particles treated at $1400^{\circ} \mathrm{C}$, despite the presence of a silica cristobalite layer around $\mathrm{SiC}$ grains, presented a TNF $\alpha$ production equivalent to that of the negative control and significantly lower than their original counterparts. Some studies indicate that cristobalite originated by heating quartz at high temperature $\left(>1300^{\circ} \mathrm{C}\right)$, as well heated cristobalite, exhibits higher 
hydrophobicity and lower amount of surface radicals (Fubini et al., 1995b, 1995a) if compared to other cristobalite samples, such as those originated from diatomaceous earth heated at $1000^{\circ} \mathrm{C}$. Heated cristobalite also exhibits a lower toxicity in cell free tests (Fubini et al., 1999). This may partially explain the limited pro-inflammatory effect of industrial SiC powders treated at $1400^{\circ} \mathrm{C}$.

Oxidation of $\mathrm{SiC} \mathrm{C1}$ did not influence the $\mathrm{H}_{2} \mathrm{O}_{2}$ production (Figure 9A). Although oxidized SiC F1 exhibited a $\mathrm{H}_{2} \mathrm{O}_{2}$ generation higher than that of the positive control (irrespective of the temperature), it remained in the same range as the original $\mathrm{SiC} \mathrm{F} 1$ powder, except at $750^{\circ} \mathrm{C}$

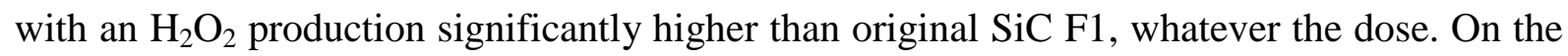
contrary $\mathrm{H}_{2} \mathrm{O}_{2}$ production for $\mathrm{SiC} \mathrm{F} 1-650^{\circ} \mathrm{C}$ was significantly less than for original $\mathrm{SiC} \mathrm{F} 1$, whatever the particles dose. We have finally calculated the $\mathrm{R}^{2}$ coefficient between $\mathrm{H}_{2} \mathrm{O}_{2}$

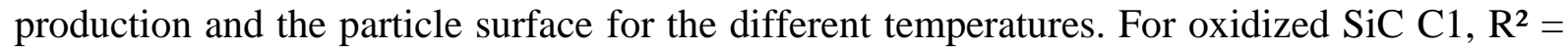
0.471 and for oxidized $\mathrm{SiC} \mathrm{F1,} \mathrm{R}^{2}=0.667$ (data not shown). These results suggested that the production of $\mathrm{H}_{2} \mathrm{O}_{2}$ was not dependent on the degree of oxidation and iron content (Table 3). The different behavior between oxidized SiC C1 and F1 could be once again explained by a particle size effect.

The increasing amorphous surface layer and progressive conversion of $\mathrm{Fe}^{2+}$ into $\mathrm{Fe}^{3+}$ following oxidation at low temperatures $\left(<850^{\circ} \mathrm{C}\right)$ are likely responsible for the decrease in free radical generation (Figure 10). The decrease was more noticeable for carboxyl than for hydroxyl radicals. Although the mechanism of $\mathrm{COO}^{*-}$ generation is not still fully clarified, the reduction of reactivity subsequent to oxidation of active surface sites has been observed also in other particulates (Tomatis et al., 2002). However, SiC C1 and F1 oxidized at $1400^{\circ} \mathrm{C}$ showed an increased capacity to generate an EPR signal, mainly for $\mathrm{HO}^{\bullet}$ but also for $\mathrm{COO}^{\circ-}$ radicals even if for this latter the effect was much less pronounced (Figure 10). At this treatment temperature, two correlations can be established: between $\mathrm{HO}^{\bullet}, \mathrm{COO}^{\circ-}$ radicals and 
crystallization on the one hand (cristobalite > amorphous $\mathrm{SiO}_{2}$ ) and between $\mathrm{HO}^{\circ}, \mathrm{COO}^{\circ}$ radicals and size on the other hand (coarse oxidized $\mathrm{SiC} \mathrm{C1}>$ fine oxidized SiC F1, Table 3). These observations were in agreement with previous literature studies describing specifically a more important toxicity associated with a higher radical potential for crystallized silica compared to amorphous $\mathrm{SiO}_{2}$ (Fubini et al., 1999; Fubini and Hubbard, 2003). Finally, we have observed as for original $\mathrm{SiC} \mathrm{C} 1$ and $\mathrm{F} 1$ powders an opposite trend between cellular oxidative stress $\left(\mathrm{H}_{2} \mathrm{O}_{2}\right.$ production) and free radical generation in cell free conditions. The EPR radical potential was temperature-dependent and directly related to the silica phase nature: amorphous $\mathrm{SiO}_{2}$ at 650,750 and $850^{\circ} \mathrm{C}$ compared to cristobalite $\mathrm{SiO}_{2}$ at $1400^{\circ} \mathrm{C}$ (Table 2).

\section{Conclusion}

Particle and fibre toxicology is known to be closely related to their physico-chemical properties (size, shape, surface area, chemical composition, etc.). In order to deepen such a relationship, a thorough physico-chemical characterization of different $\mathrm{SiC}$ powders manufactured through the Acheson process and collected at workplace was carried out, in association with an in vitro evaluation of their biological activity. Table 3 summarizes the relationships put in evidence in the present study.

We have thereby demonstrated that all types of industrial $\mathrm{SiC}$ particles tested did not induce any significant cytotoxic effect. Three parameters having an influence on the in vitro biological response were identified: the particle size, the presence of iron impurities at the particle surface and the oxidation state.

The particle size was found to have an impact on $\mathrm{SiC}$ powders related to $\mathrm{H}_{2} \mathrm{O}_{2}$ production oxidative stress, with a significantly higher impact for fine $\mathrm{SiC}$ particles. Size of oxidized fine SiC F1 seems to have also an influence especially on cytotoxicity and to a lesser extent on 
oxidative stress. The presence of iron metallic impurities at the surface of the particles mainly stimulated a pro-inflammatory TNF $\alpha$ response which was abolished when amorphous $\mathrm{SiO}_{2}$ was transformed into cristobalite at $1400^{\circ} \mathrm{C}$. The oxidation surface modifications by this $1400^{\circ} \mathrm{C}$ thermal treatment seemed to also have a deep impact on $\mathrm{HO}^{\circ}$ and $\mathrm{COO}^{-}$radical generation.

Taken together these results support the conclusion that the various manufactured $\mathrm{SiC}$ powders collected from Acheson process workplace, do not induce similar levels of toxicity, underlining the need to systematically evaluate the biological activity in relation to the particles physico-chemical features through case by case studies. Furthermore, the modification of particles surface has clearly emphasized the major importance of surface oxidation state, in addition to more usual physico-chemical features such as size, SSA, shape or chemical composition.

This approach combining systematically physico-chemical characterization and biological assessment is particularly recommended in the evaluation of occupational risks in industrial environments or in the context of "safer by design" principles (Morose, 2010). By tightly controlling the physico-chemical features of the industrial SiC particles, pro-inflammatory effect and oxidative stress could be limited. A particularly interesting observation is that $\mathrm{SiC}$ toxicity manufactured through the Acheson process seems to be modulated by the oxidized external layer around $\mathrm{SiC}$ grains. It opens new perspectives in the preparation of industrial powders as the prevention of potential hazard seems easier at the design stage than during the manufacturing processes or at the customer use level. 


\section{Funding information}

This work was supported by the French Ministry of Industry and an industrial partner.

\section{Supporting information available}

Supplementary Figure 1 representing the relationship between the $\mathrm{H}_{2} \mathrm{O}_{2}$ production and the particle surface. This material is available online. 


\section{References}

Acheson, E.G., 1893. Production of artificial crystalline carbonaceous materials.

Akiyama, I., Ogami, A., Oyabu, T., Yamato, H., Morimoto, Y., Tanaka, I., 2007. Pulmonary effects and biopersistence of deposited silicon carbide whisker after 1-year inhalation in rats. Inhal. Toxicol. 19, 141-147.

Allen, M., Butter, R., Chandra, L., Lettington, A., Rushton, N., 1995. Toxicity of particulate silicon carbide for macrophages, fibroblasts and osteoblast-like cells in vitro. Biomed. Mater. Eng. 5, 151-159.

Aust, A.E., Lund, L.G., Chao, C.C., Park, S.H., Fang, R.H., 2000. Role of iron in the cellular effects of asbestos. Inhal. Toxicol. 12, 75-80.

Barillet, S, Jugan, M.-L., Laye, M., Leconte, Y., Herlin-Boime, N., Reynaud, C., Carrière, M., 2010. In vitro evaluation of SiC nanoparticles impact on A549 pulmonary cells: cyto-, genotoxicity and oxidative stress. Toxicol. Lett. 198, 324-330.

Barillet, Sabrina, Simon-Deckers, A., Herlin-Boime, N., Mayne-L'Hermite, M., Reynaud, C., Cassio, D., Gouget, B., Carriere, M., 2010. Toxicological consequences of TiO2, SiC nanoparticles and multi-walled carbon nanotubes exposure in several mammalian cell types: an in vitro study. J. Nanoparticle Res. 12, 61-73.

Boumahdi, N., 2009. Approche pluridisciplinaire de l'étude de l'activité biologique de particules fines (Thèse de doctorat). École nationale supérieure des mines, Saint-Etienne, France.

Brown, D.M., Wilson, M.R., MacNee, W., Stone, V., Donaldson, K., 2001. Size-dependent proinflammatory effects of ultrafine polystyrene particles: a role for surface area and oxidative stress in the enhanced activity of ultrafines. Toxicol. Appl. Pharmacol. 175, 191199.

Bruch, J., Rehn, B., 1996. Relevant differences in pathogenicity of nuisance dusts; model investigations on samples of silicon carbide dusts. Exp. Toxicol. Pathol. Off. J. Ges. Für Toxikol. Pathol. 48, 477-480.

Bruch, J., Rehn, B., Song, H., Gono, E., Malkusch, W., 1993a. Toxicological investigations on silicon carbide. 1. Inhalation studies. Br. J. Ind. Med. 50, 797-806.

Bruch, J., Rehn, B., Song, W., Gono, E., Malkusch, W., 1993b. Toxicological investigations on silicon carbide. 2. In vitro cell tests and long term injection tests. Br. J. Ind. Med. 50, 807-813.

Bruch, J., Rehn, S., Rehn, B., Borm, P.J.A., Fubini, B., 2004. Variation of biological responses to different respirable quartz flours determined by a vector model. Int. J. Hyg. Environ. Health 207, 203-216. 
Bruusgaard A., 1948. Pneumoconiosis in silicon carbide workers. Proc. 9th Int. Congr. Ind. Med. Lond. U. K. Wright Briston 676-81.

Cichy, B., 1989. Pathogenic and carcinogenic properties of silicon carbide. Pol. J. Occup. Med. 2, 87-96.

Cullen, R.T., Miller, B.G., Davis, J.M., Brown, D.M., Donaldson, K., 1997. Short-term inhalation and in vitro tests as predictors of fiber pathogenicity. Environ. Health Perspect. 105 Suppl 5, 1235-1240.

Das, D., Farjas, J., Roura, P., 2004. Passive-oxidation kinetics of SiC microparticles. J. Am. Ceram. Soc. 87, 1301-1305.

De la Harpe, J., Nathan, C.F., 1985. A semi-automated micro-assay for $\mathrm{H} 2 \mathrm{O} 2$ release by human blood monocytes and mouse peritoneal macrophages. J. Immunol. Methods 78, 323-336.

Deal, B.E., Grove, A.S., 1965. General Relationship for the Thermal Oxidation of Silicon. J. Appl. Phys. 36, 3770-3778.

Donaldson, K., Brown, D., Clouter, A., Duffin, R., MacNee, W., Renwick, L., Tran, L., Stone, V., 2002. The pulmonary toxicology of ultrafine particles. J. Aerosol Med.-Depos. Clear. Eff. Lung 15, 213-220.

Dufresne, A., Sébastien, P., Perrault, G., Massé, S., Bégin, R., 1992. Pulmonary clearance of fibrous and angular $\mathrm{SiC}$ particulates in the sheep model of pneumoconiosis. Ann. Occup. Hyg. 36, 519-530.

Fenoglio, I., Prandi, L., Tomatis, M., Fubini, B., 2001. Free radical generation in the toxicity of inhaled mineral particles: the role of iron speciation at the surface of asbestos and silica. Redox Rep. Commun. Free Radic. Res. 6, 235-241.

Filipuzzi, L., 1991. Oxydation des composites SIC/SIC et de leurs constituants : approche expérimentale, modélisation et influence sur le comportement mécanique (Thèse de doctorat). [s.n.], [S.1.], France.

Fubini, B., Bolis, V., Cavenago, A., Volante, M., 1995a. Physicochemical properties of crystalline silica dusts and their possible implication in various biological responses. Scand. J. Work. Environ. Health 21 Suppl 2, 9-14.

Fubini, B., Fenoglio, I., Ceschino, R., Ghiazza, M., Martra, G., Tomatis, M., Borm, P., Schins, R., Bruch, J., 2004. Relationship between the state of the surface of four commercial quartz flours and their biological activity in vitro and in vivo. Int. J. Hyg. Environ. Health 207, 89-104.

Fubini, B., Hubbard, A., 2003. Reactive oxygen species (ROS) and reactive nitrogen species (RNS) generation by silica in inflammation and fibrosis. Free Radic. Biol. Med. 34, 1507-1516. 
Fubini, B., Mollo, L., Giamello, E., 1995b. Free radical generation at the solid/liquid interface in iron containing minerals. Free Radic. Res. 23, 593-614.

Fubini, B., Zanetti, G., Altilia, S., Tiozzo, R., Lison, D., Saffiotti, U., 1999. Relationship between surface properties and cellular responses to crystalline silica: studies with heattreated cristobalite. Chem. Res. Toxicol. 12, 737-745.

Fubini, B, 2007. Particules ultra-fines : propriétés physicochimiques et activité biologique, in: Les Nanoparticules: Un Enjeu Majeur Pour La Santé Au Travail? EDP Sciences, France, pp. 499-529.

Funahashi, A., Schlueter, D.P., Pintar, K., Siegesmund, K.A., Mandel, G.S., Mandel, N.S., 1984. Pneumoconiosis in workers exposed to silicon carbide. Am. Rev. Respir. Dis. 129, $635-640$.

Governa, M., Amati, M., Fenoglio, I., Valentino, M., Coloccini, S., Bolognini, L., Carlo Botta, G., Emanuelli, M., Pierella, F., Volpe, A.R., Astolfi, P., Carmignani, M., Fubini, B., 2005. Variability of biological effects of silicas: different degrees of activation of the fifth component of complement by amorphous silicas. Toxicol. Appl. Pharmacol. 208, 68-77.

Halliwell, B., Gutteridge, J.M., 1992. Biologically relevant metal ion-dependent hydroxyl radical generation. An update. FEBS Lett. 307, 108-112.

Hayashi, H., Kajita, A., 1988. Silicon carbide in lung tissue of a worker in the abrasive industry. Am. J. Ind. Med. 14, 145-155.

Höhr, D., Steinfartz, Y., Schins, R.P.F., Knaapen, A.M., Martra, G., Fubini, B., Borm, P.J.A., 2002. The surface area rather than the surface coating determines the acute inflammatory response after instillation of fine and ultrafine $\mathrm{TiO} 2$ in the rat. Int. J. Hyg. Environ. Health 205, 239-244.

IARC, 1996. IARC Monograph on the Evaluation of Carcinogenic Risks to Humans. (Printing Processes and Printing Inks, Carbon Black and Some Nitro Compounds). IARC, Lyon, France.

Leclerc, L., Boudard, D., Pourchez, J., Forest, V., Sabido, O., Bin, V., Palle, S., Grosseau, P., Bernache, D., Cottier, M., 2010. Quantification of microsized fluorescent particles phagocytosis to a better knowledge of toxicity mechanisms. Inhal. Toxicol. 22, 10911100 .

Massé, S., Bégin, R., Cantin, A., 1988. Pathology of silicon carbide pneumoconiosis. Mod. Pathol. Off. J. U. S. Can. Acad. Pathol. Inc 1, 104-108.

Morose, G., 2010. The 5 principles of "Design for Safer Nanotechnology". J. Clean. Prod. 18, 285-289.

Oberdorster, G., 2000. Toxicology of ultrafine particles: in vivo studies. Philos. Trans. R. Soc. Lond. Ser. -Math. Phys. Eng. Sci. 358, 2719-2739. 
Oberdörster, G., Ferin, J., Lehnert, B.E., 1994. Correlation between particle size, in vivo particle persistence, and lung injury. Environ. Health Perspect. 102 Suppl 5, 173-179.

Oberdörster, G., Oberdörster, E., Oberdörster, J., 2005. Nanotoxicology: an emerging discipline evolving from studies of ultrafine particles. Environ. Health Perspect. 113, 823839.

Osterman, J.W., Greaves, I.A., Smith, T.J., Hammond, S.K., Robins, J.M., Thériault, G., 1989. Work related decrement in pulmonary function in silicon carbide production workers. Br. J. Ind. Med. 46, 708-716.

Pham-Huu, C., Bouchy, C., Dintzer, T., Ehret, G., Estournes, C., Ledoux, M.J., 1999. High surface area silicon carbide doped with zirconium for use as catalyst support. Preparation, characterization and catalytic application. Appl. Catal. -Gen. 180, 385-397.

Pierre, J.L., Fontecave, M., 1999. Iron and activated oxygen species in biology: the basic chemistry. Biometals Int. J. Role Met. Ions Biol. Biochem. Med. 12, 195-199.

Pourchez, J., Forest, V., Boumahdi, N., Boudard, D., Tomatis, M., Fubini, B., Herlin-Boime, N., Leconte, Y., Guilhot, B., Cottier, M., Grosseau, P., 2012. In vitro cellular responses to silicon carbide nanoparticles: impact of physico-chemical features on pro-inflammatory and pro-oxidative effects. J. Nanoparticle Res. 14, 1143.

Pritchard, R.J., Ghio, A.J., Lehmann, J.R., Winsett, D.W., Tepper, J.S., Park, P., Gilmour, M.I., Dreher, K.L., Costa, D.L., 1996. Oxidant generation and lung injury after particulate air pollutant exposure increase with the concentrations of associated metals. Inhal. Toxicol. 8, 457-477.

Shi, Z.L., Lee, J., Zhang, D., Lee, H., Gu, M.Y., Wu, R.J., 2001. The passive-oxidized behavior of SiC particles and their jointing characteristics. J. Mater. Process. Technol. $110,127-131$.

Svensson, I., Artursson, E., Leanderson, P., Berglind, R., Lindgren, F., 1997. Toxicity in vitro of some silicon carbides and silicon nitrides: whiskers and powders. Am. J. Ind. Med. 31, $335-343$.

Tomatis, M., Prandi, L., Bodoardo, S., Fubini, B., 2002. Loss of Surface Reactivity upon Heating Amphibole Asbestos. Langmuir 18, 4345-4350.

Turci, F., Tomatis, M., Lesci, I.G., Roveri, N., Fubini, B., 2011. The iron-related molecular toxicity mechanism of synthetic asbestos nanofibres: a model study for high-aspect-ratio nanoparticles. Chem. Weinh. Bergstr. Ger. 17, 350-358.

Van Maanen, J.M., Borm, P.J., Knaapen, A., van Herwijnen, M., Schilderman, P.A., Smith, K.R., Aust, A.E., Tomatis, M., Fubini, B., 1999. In vitro effects of coal fly ashes: hydroxyl radical generation, iron release, and DNA damage and toxicity in rat lung epithelial cells. Inhal. Toxicol. 11, 1123-1141. 
Vaughan, G.L., Trently, S.A., Wilson, R.B., 1993. Pulmonary response, in vivo, to silicon carbide whiskers. Environ. Res. 63, 191-201.

Winslow, C.-E.A., Greenburg, L., Greenberg, D., 1919. The Dust Hazard in the Abrasive Industry. Public Health Rep. 1896-1970 34, 1171-1187. 


\section{Figure legends}

Figure 1 - Morphological aspect of SiC microparticles observed by scanning electron microscopy. A) SiC C1 representative of coarse particles, B) SiC F2 representative of fine particles.

Figure 2 - Cytotoxicity of the different SiC microparticles determined by the LDH release. Results are means of 3 independent experiments. Standard deviation and statistically significant differences from the negative control (cells incubated without particles) are also indicated: $* * * \mathrm{p}<0.001$ (two-way ANOVA test).

Figure 3 - Pro-inflammatory effect of the different SiC microparticles determined by the $\mathrm{TNF} \alpha$ production. Results are means of 3 independent experiments. Standard deviation and statistically significant differences from the negative control (cells incubated without particles) are also indicated: $* * * \mathrm{p}<0.001$ (two-way ANOVA test).

Figure 4 - Acute oxidative stress induced by the different $\mathrm{SiC}$ microparticles as assessed by the $\mathrm{H}_{2} \mathrm{O}_{2}$ production. Results are means of 3 independent experiments. Standard deviation and statistically significant differences from the negative control (cells incubated without particles) are also indicated: $* * * \mathrm{p}<0.001$ (two-way ANOVA test).

Figure 5 - Free radical release by the different $\mathrm{SiC}$ microparticles $\mathrm{A}$ ) $\mathrm{HO}^{\circ}$ and $\mathrm{B}$ ) $\mathrm{COO}^{\circ}$, as determined by electron paramagnetic resonance. A negative control (amorphous silica) and a positive control (DQ12 quartz) were included. Results are means of 3 independent experiments. Standard deviation and statistically significant differences from the negative control (amorphous silica) are also indicated: $* * * \mathrm{p}<0.001$ (two-way ANOVA test). We should also note the significant difference of behavior between coarse (SiC C1 / C2) and fine particles ( $\mathrm{SiC} \mathrm{F1} \mathrm{/} \mathrm{F2),} \mathrm{and} \mathrm{between} \mathrm{SiC}$ I and coarse / fine particles $(\mathrm{p}<0.001)$.

Figure 6 - Development of the silica layer during oxidation. FEG-SEM images of SiC particles embedded in a resin (diallylpthalate): (a) non-oxidized particles, (b) particles oxidized at $1200^{\circ} \mathrm{C} / 10 \mathrm{~h}$ in air. Large particles are illustrated to emphasize the nature of the particle surface, they are not representative of the whole powder sample which was constituted by smaller particles (see Table 1).

Figure 7 - Influence of different thermal treatments on the cytotoxicity of two SiC microparticles SiC C1 (A) and SiC F1 (B) determined by the LDH release. Results are means of 3 independent experiments. Standard deviation and statistically significant differences from the original powder ( $\mathrm{SiC} \mathrm{C1}$ and $\mathrm{SiC} \mathrm{F1} \mathrm{respectively)} \mathrm{are} \mathrm{also} \mathrm{indicated:} * * * \mathrm{p}<0.001$ (oneway ANOVA test). 
Figure 8 - Pro-inflammatory effect of the two SiC microparticles SiC C1 (A) and SiC F1 (B) after different thermal treatments determined by the TNF $\alpha$ production. Results are means of 3 independent experiments. Standard deviation and statistically significant differences from the original powder ( $\mathrm{SiC} \mathrm{C1}$ and $\mathrm{SiC} \mathrm{F1}$ respectively) are also indicated: *** $\mathrm{p}<0.001$ (one-way ANOVA test).

Figure 9 - Acute oxidative stress induced by the two $\mathrm{SiC}$ microparticles $\mathrm{SiC} \mathrm{C1}$ (A) and $\mathrm{SiC}$ F1 (B) after different thermal treatments as assessed by the $\mathrm{H}_{2} \mathrm{O}_{2}$ production. Results are means of 3 independent experiments. Standard deviation and statistically significant differences from the original powder ( $\mathrm{SiC} \mathrm{C} 1$ and $\mathrm{SiC} \mathrm{F} 1$ respectively) are also indicated: *** $\mathrm{p}<0.001$ (one-way ANOVA test).

Figure 10 - Influence of different thermal treatments of two $\mathrm{SiC}$ microparticles ( $\mathrm{SiC} \mathrm{C1}$ and $\mathrm{SiC} \mathrm{F} 1$ ) on the free radical release $\mathrm{A}$ ) $\mathrm{HO}^{\circ}$ and $\mathrm{B}$ ) $\mathrm{COO}^{-}$, as determined by electron paramagnetic resonance. Results are means of 3 independent experiments. Standard deviation and statistically significant differences from the original powder ( $\mathrm{SiC} \mathrm{C} 1$ and $\mathrm{SiC} F 1$ respectively) are also indicated: $* * * \mathrm{p}<0.001$ (one-way ANOVA test). 
Figure 1
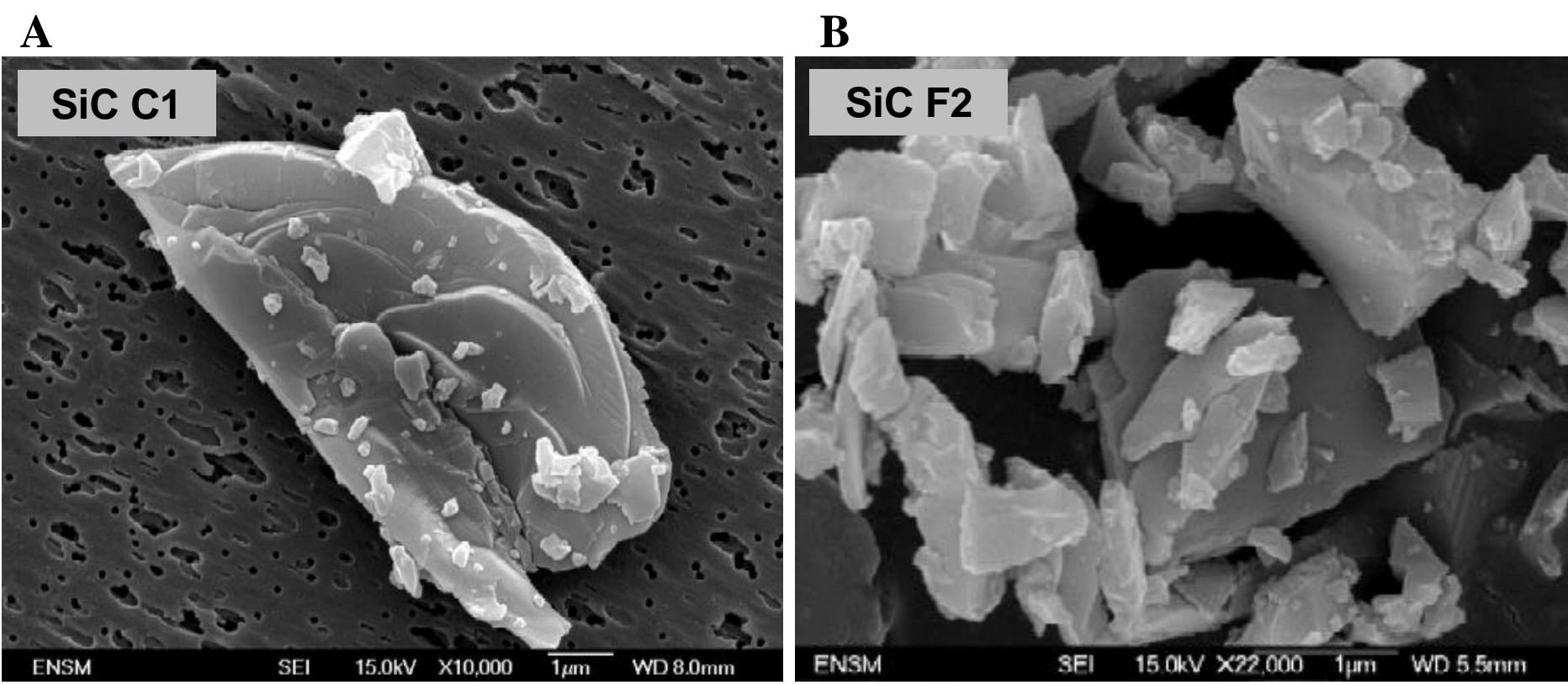
Figure 2

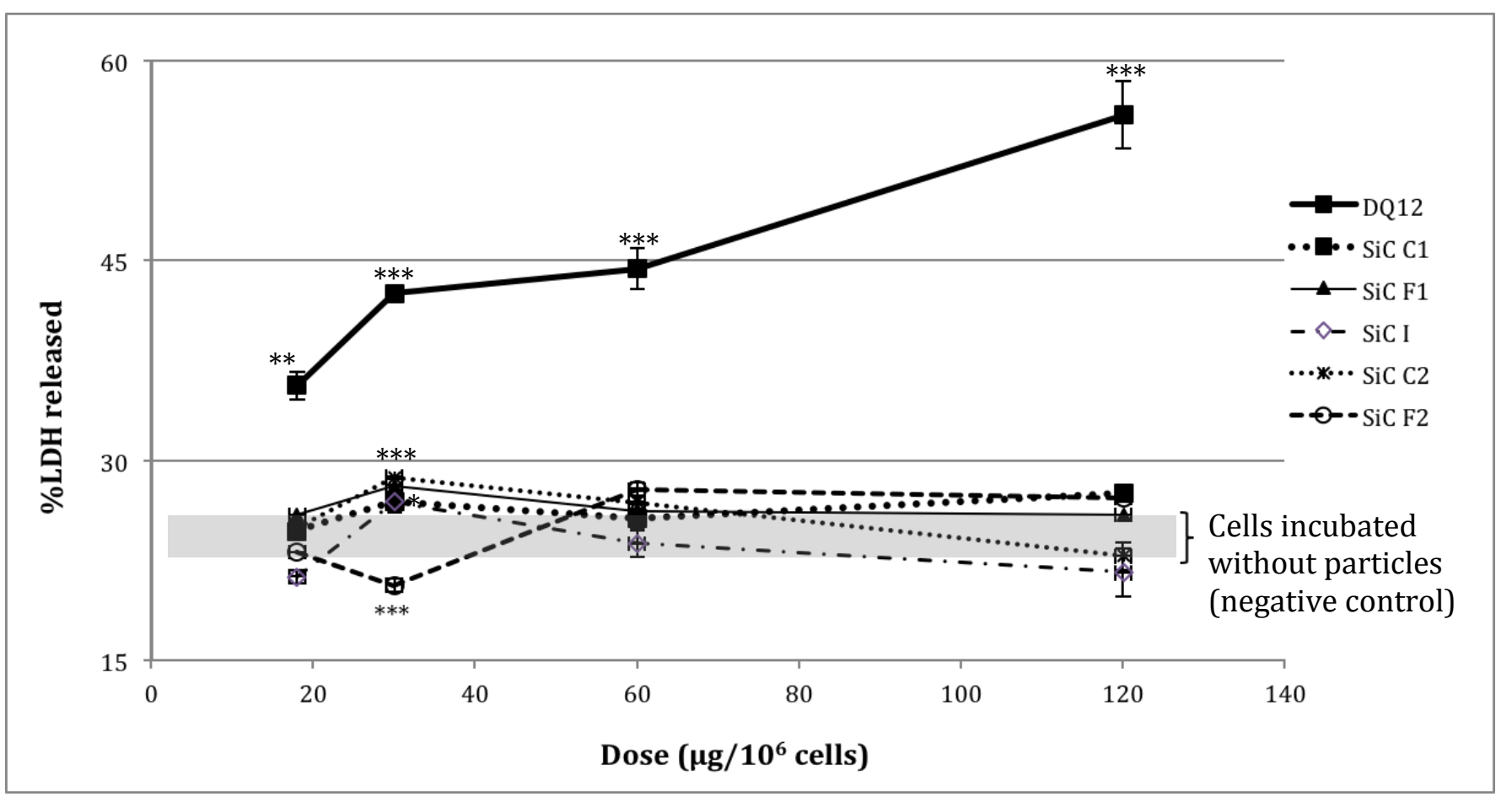


Figure 3

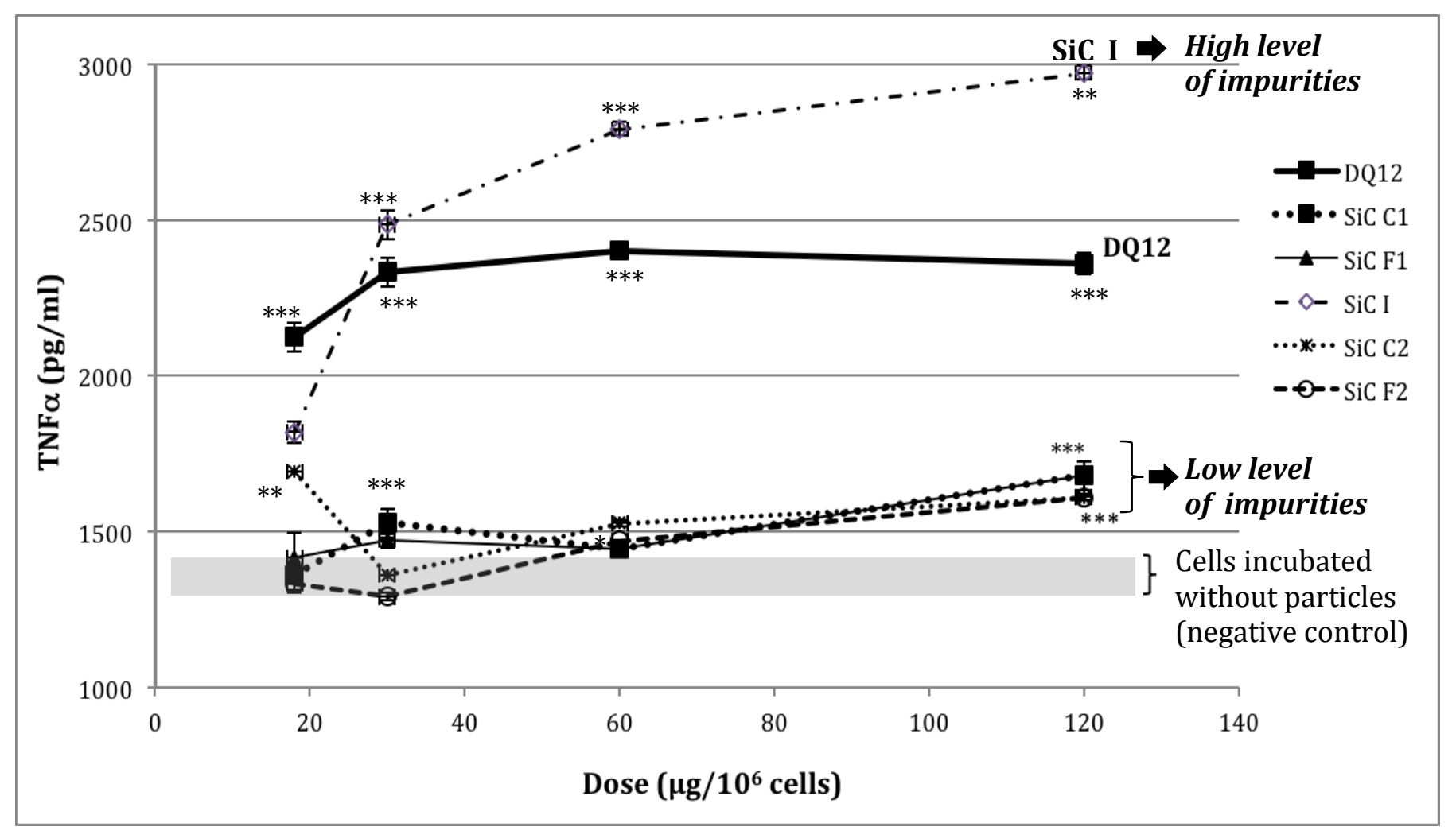




\section{Figure 4}

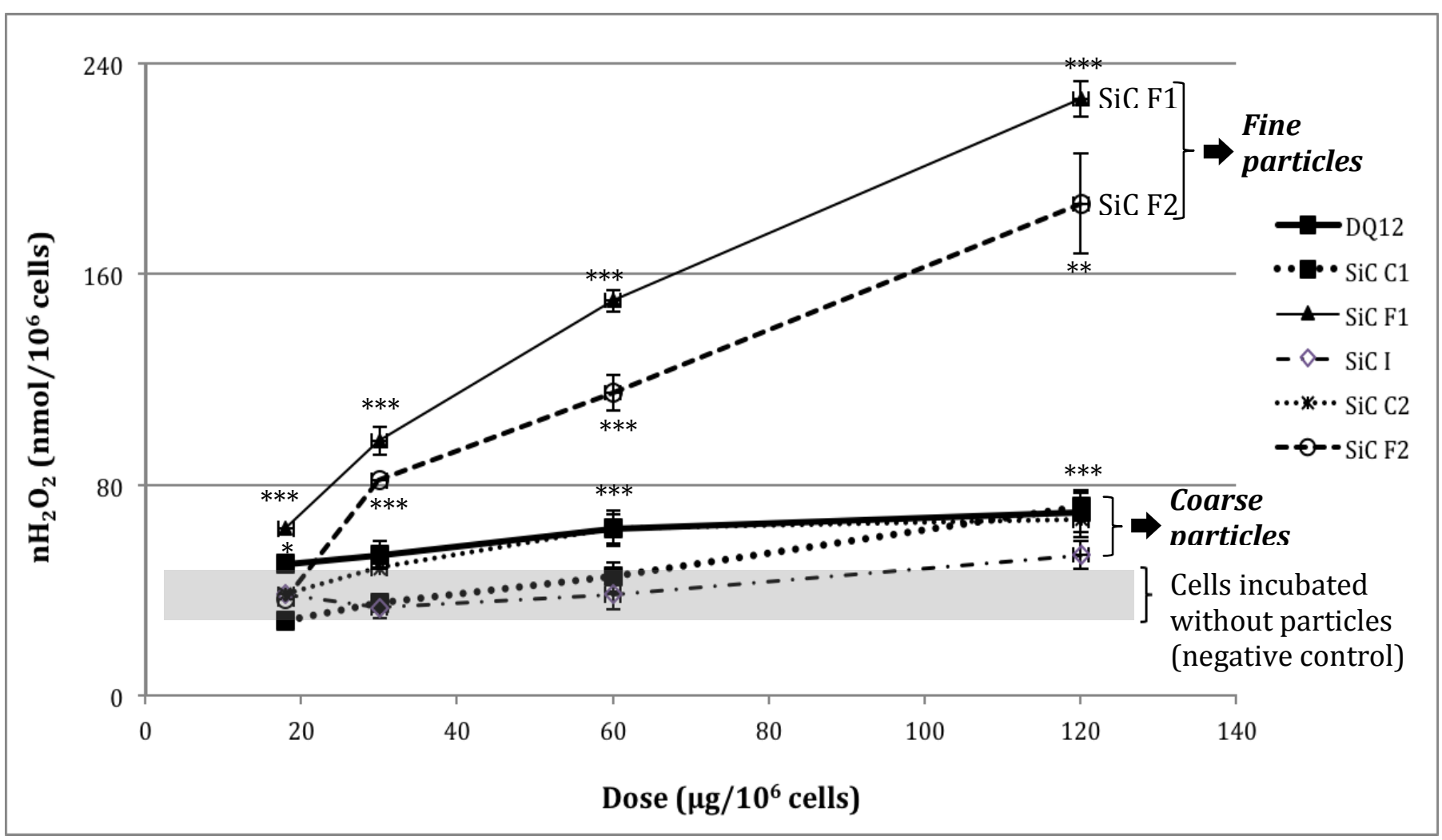


Figure 5

A

\section{$\mathrm{nsHO}^{\circ}\left(\mathrm{nmol} / \mathrm{m}^{2}\right)$}

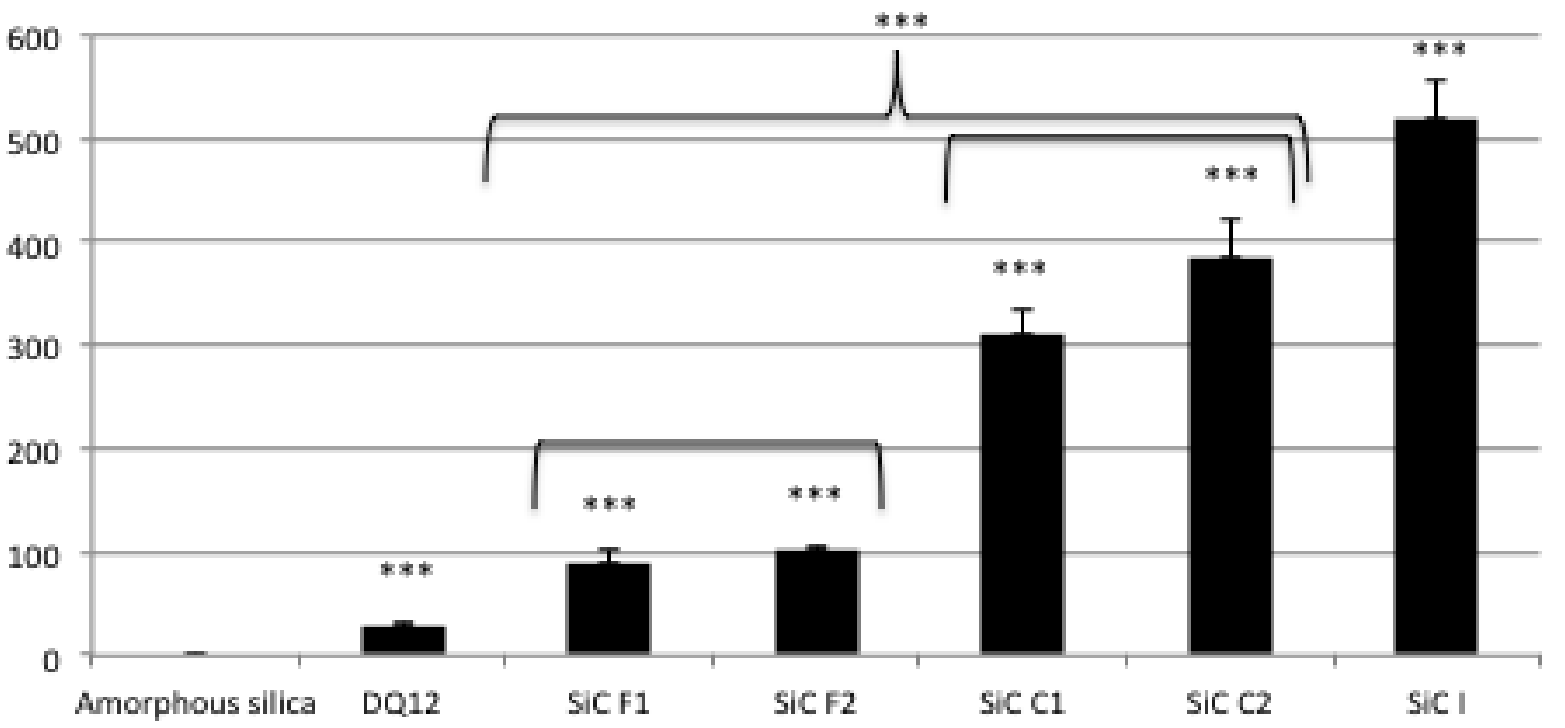

B

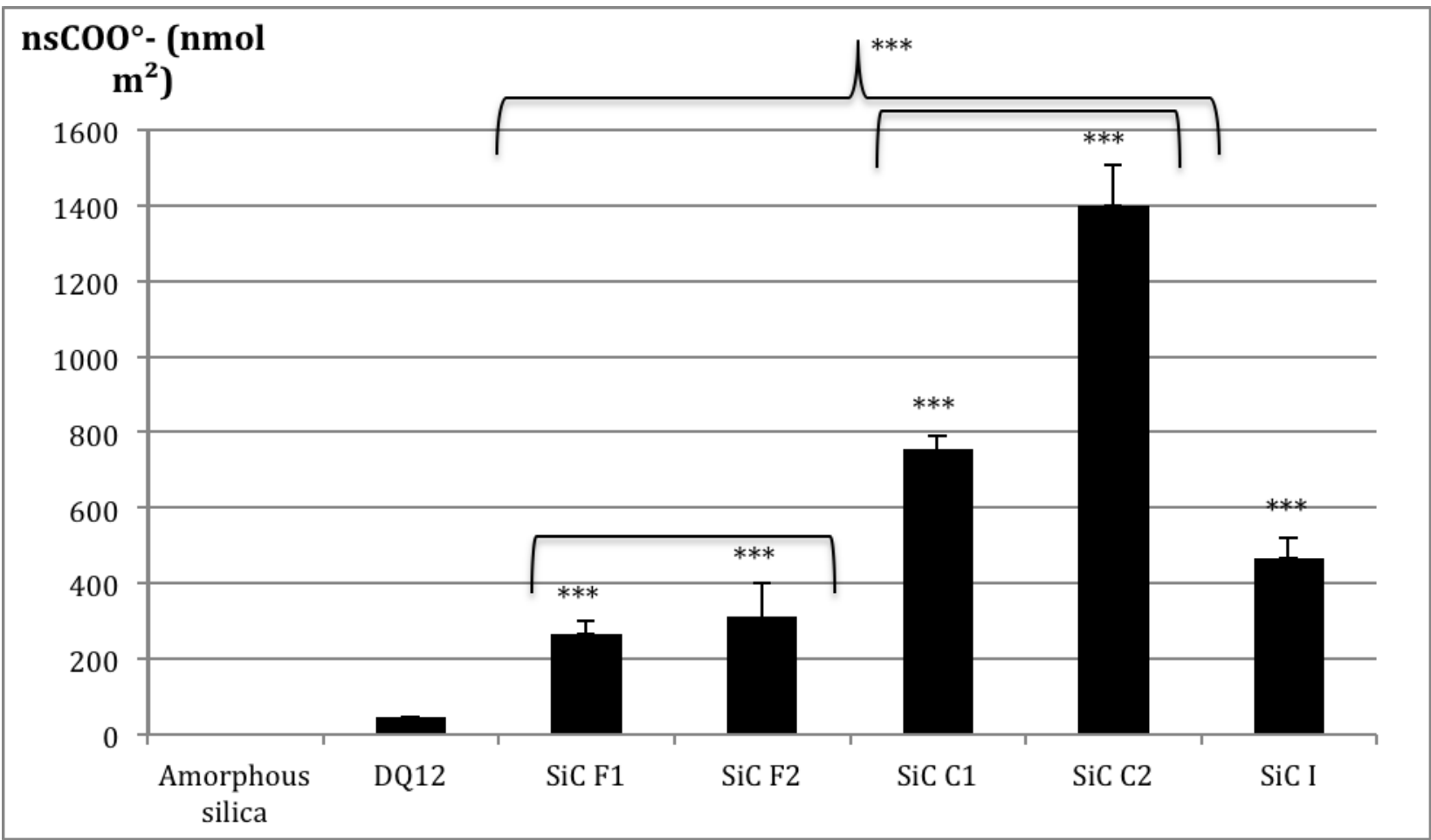


Figure 6

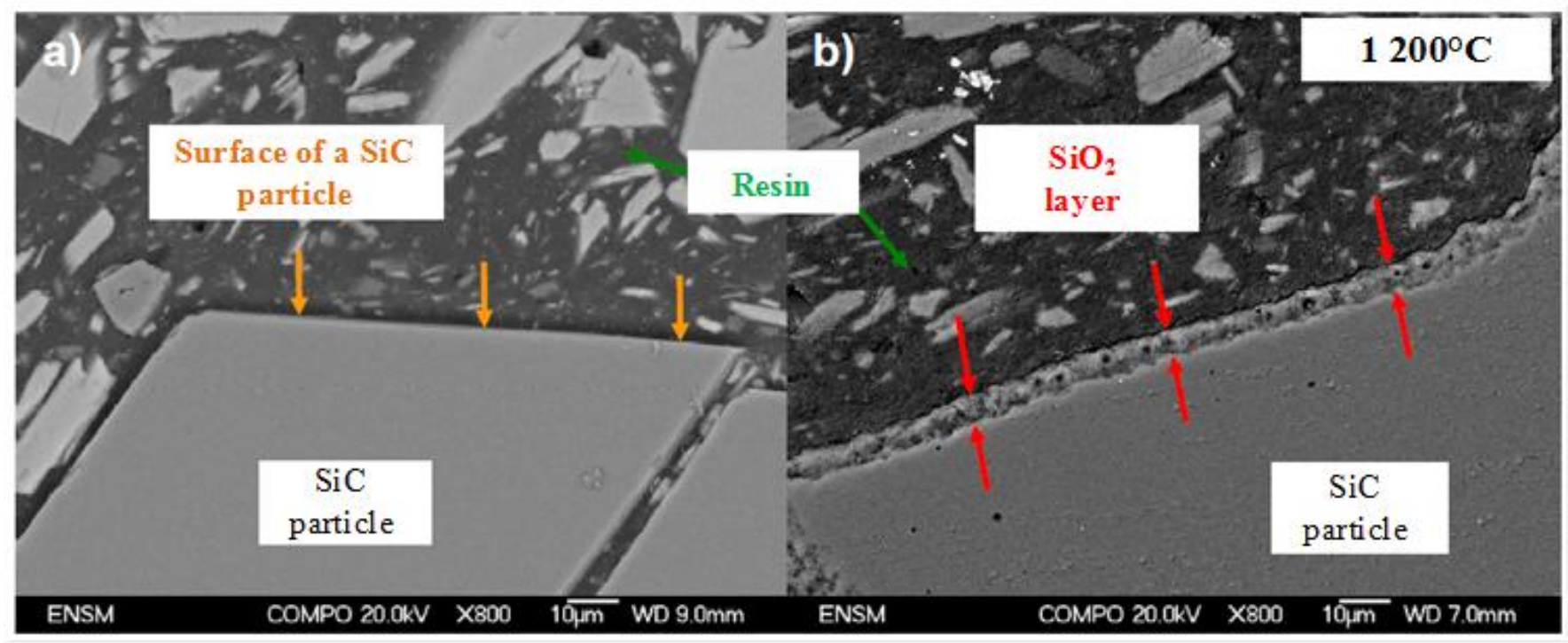


Figure 7

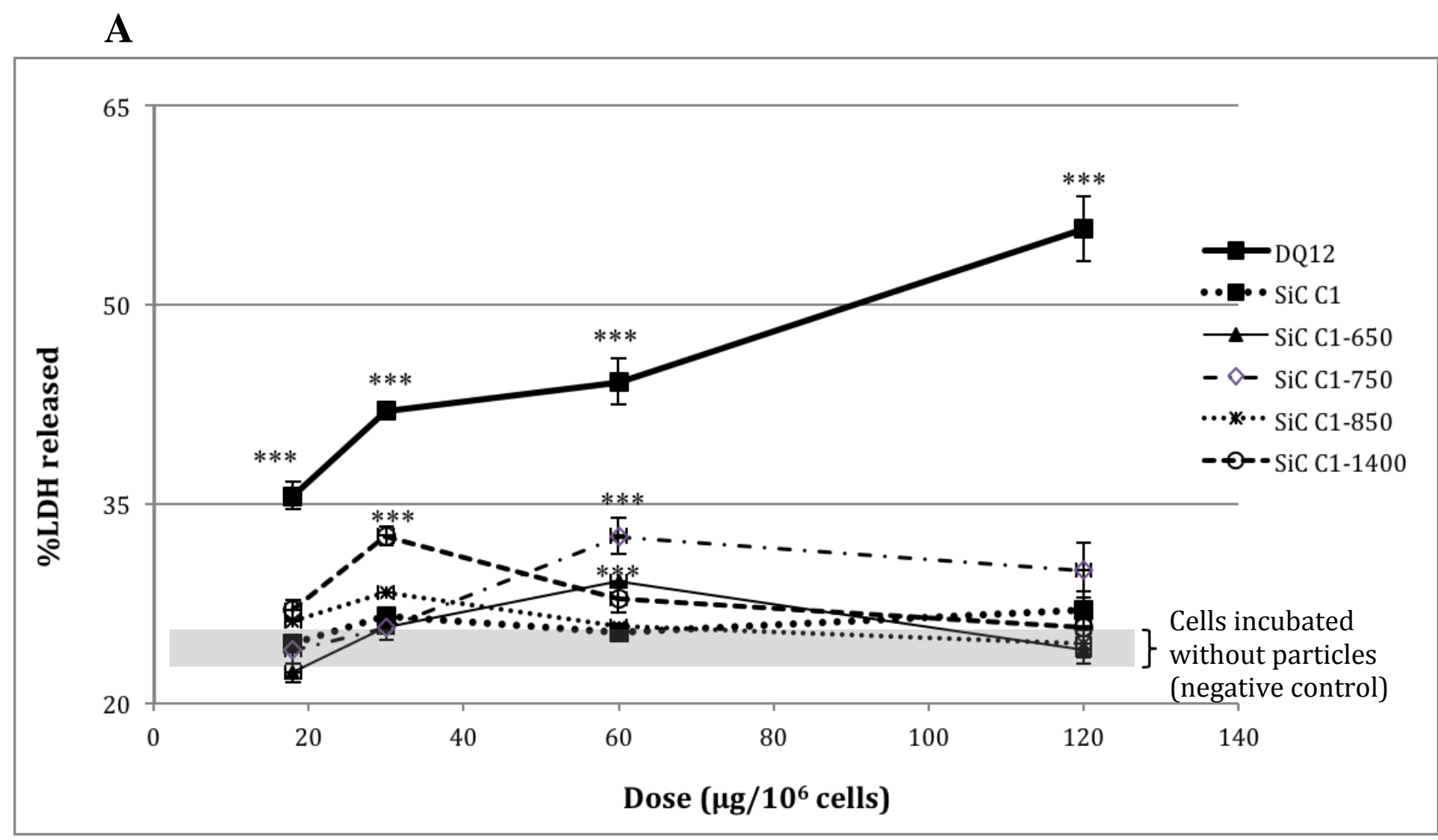

B

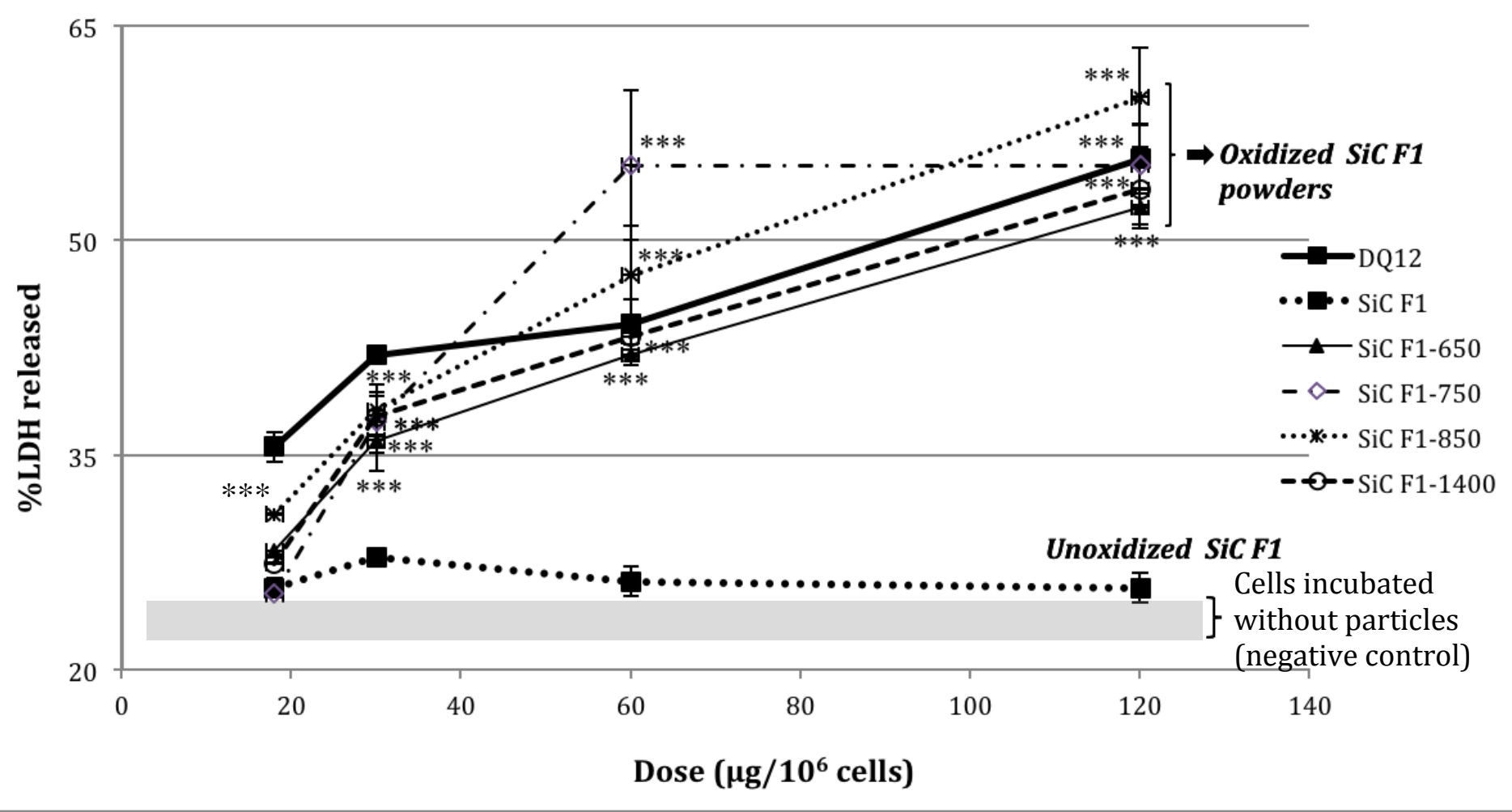




\section{Figure 8}

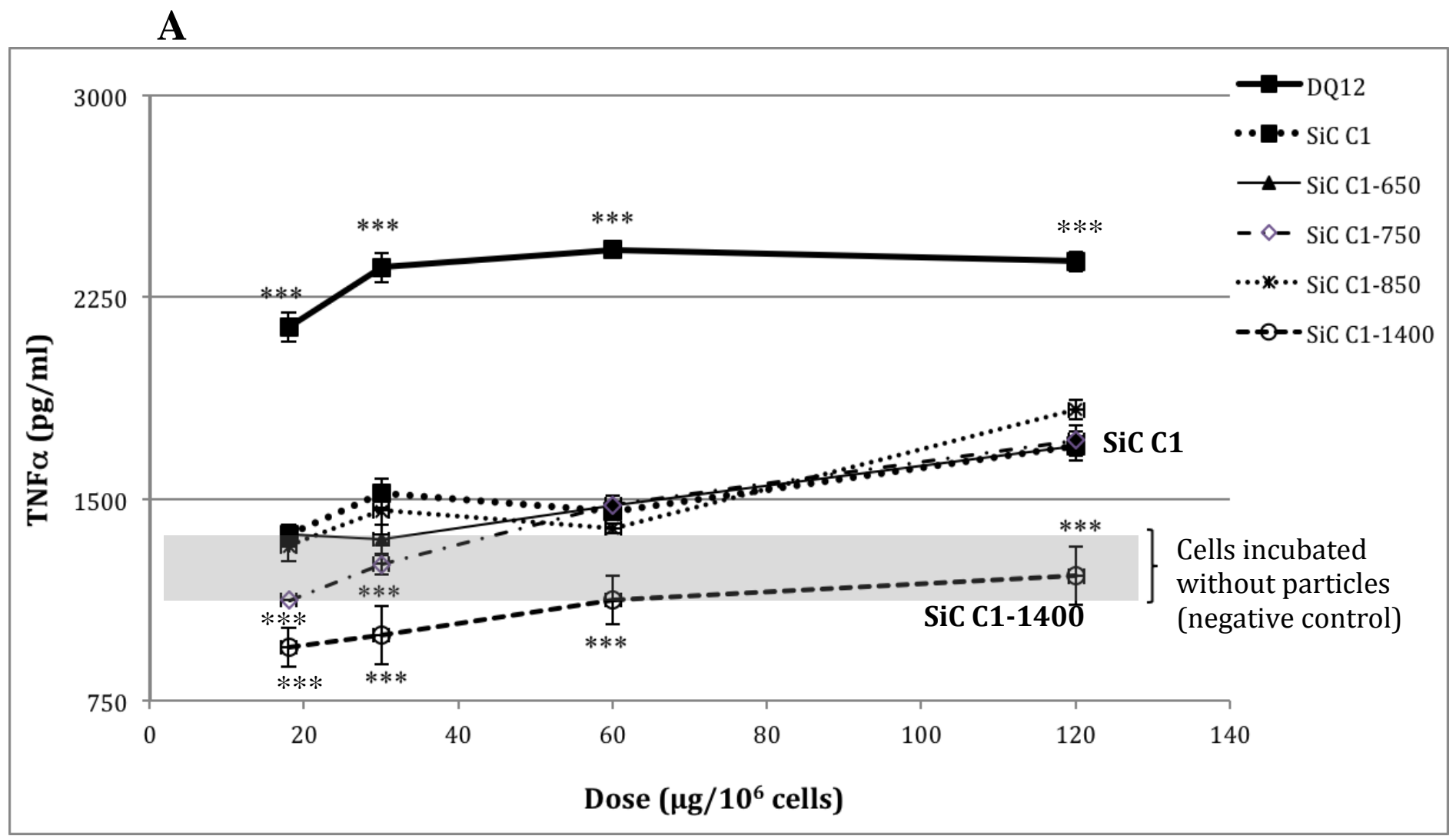

\section{B}

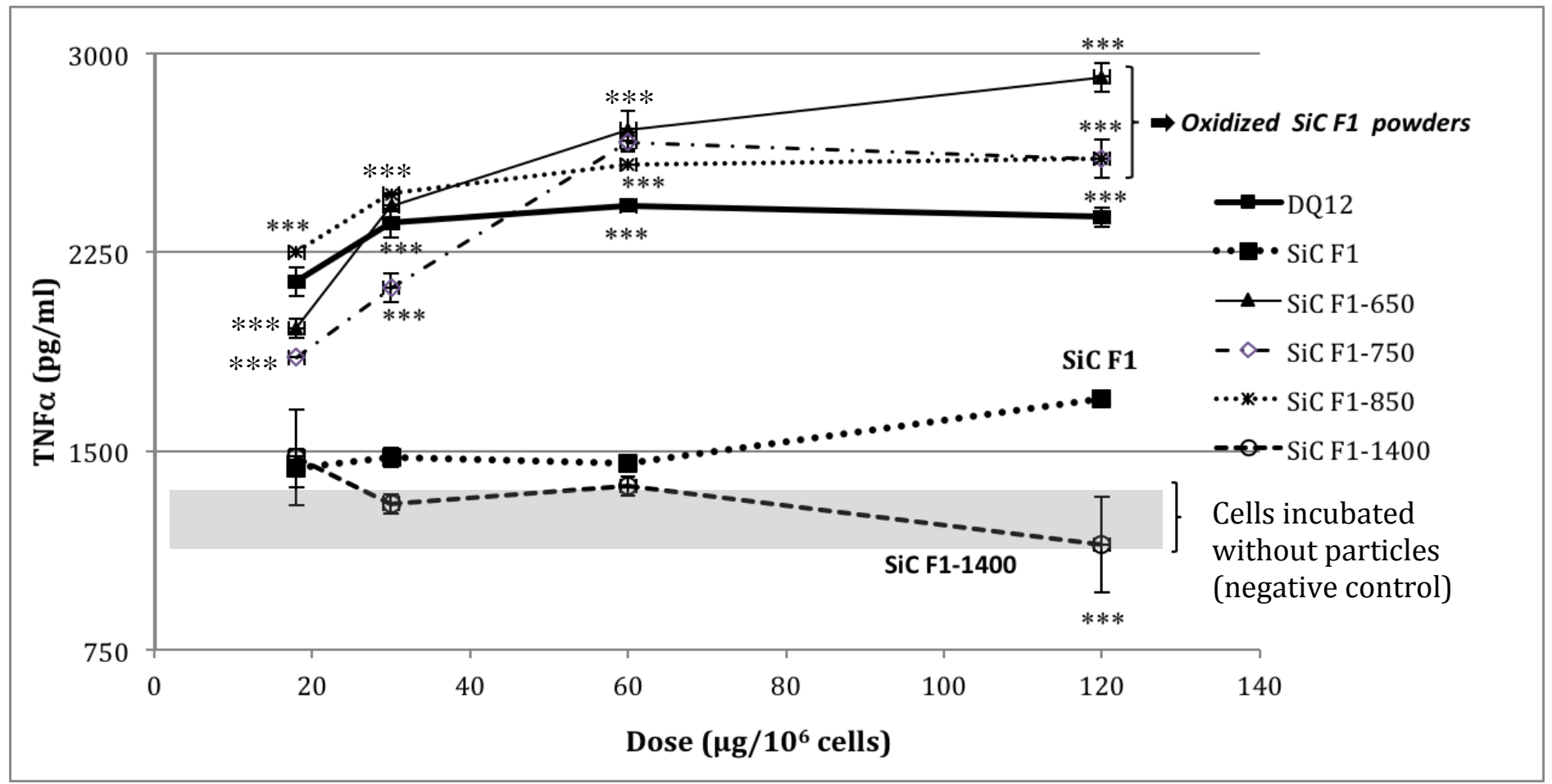




\section{Figure 9}

\section{A}

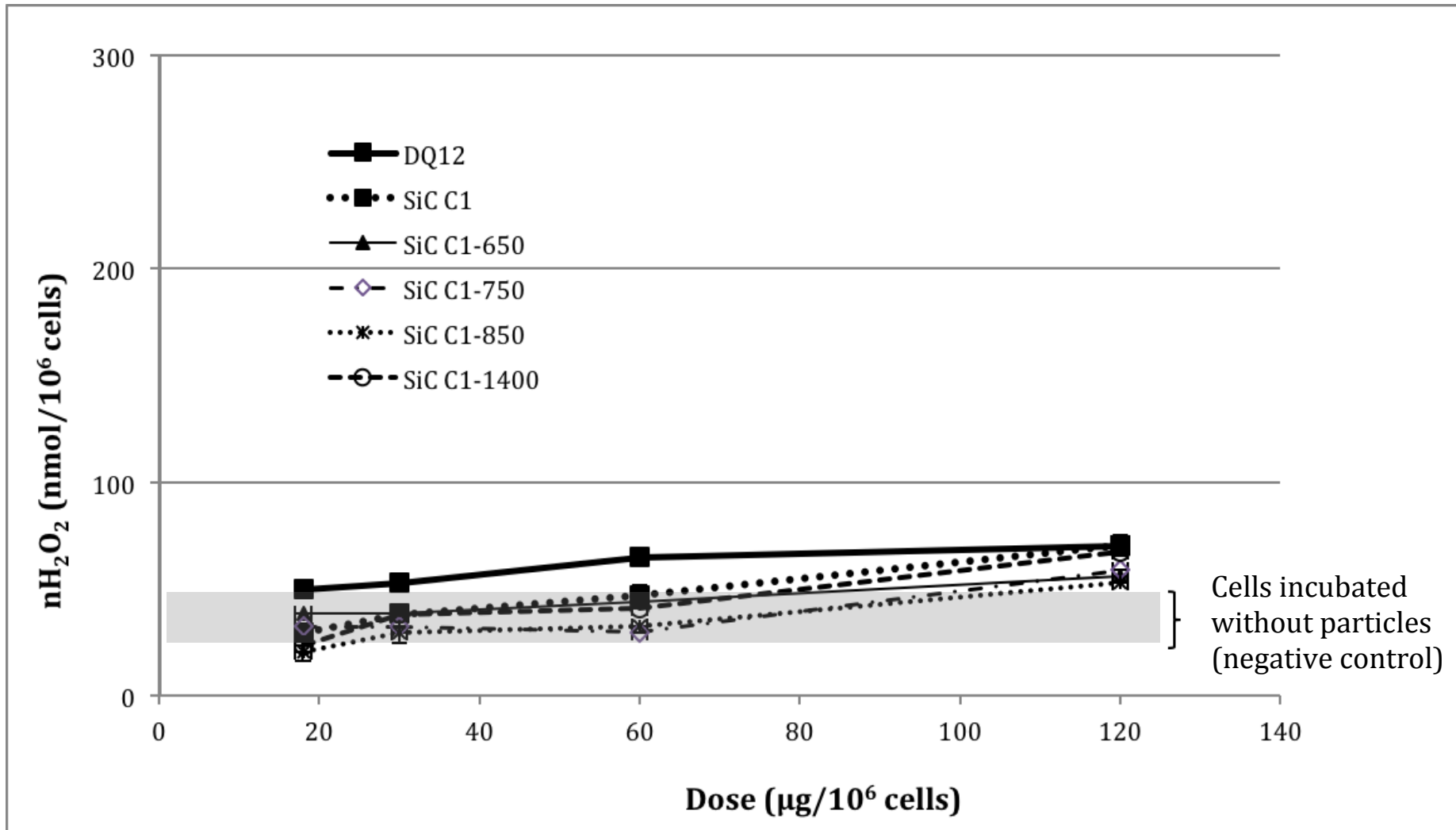

B

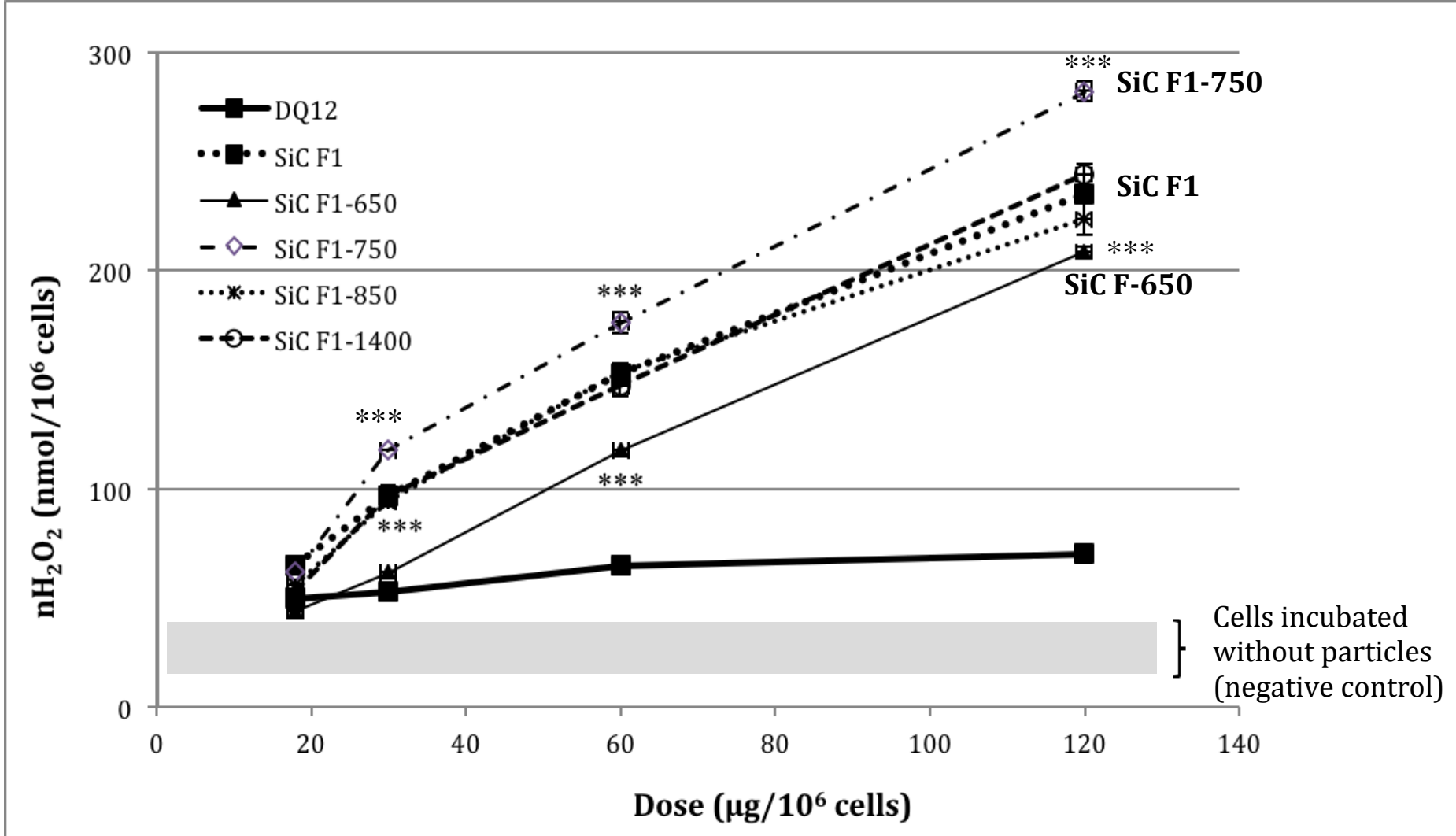


Figure 10

A

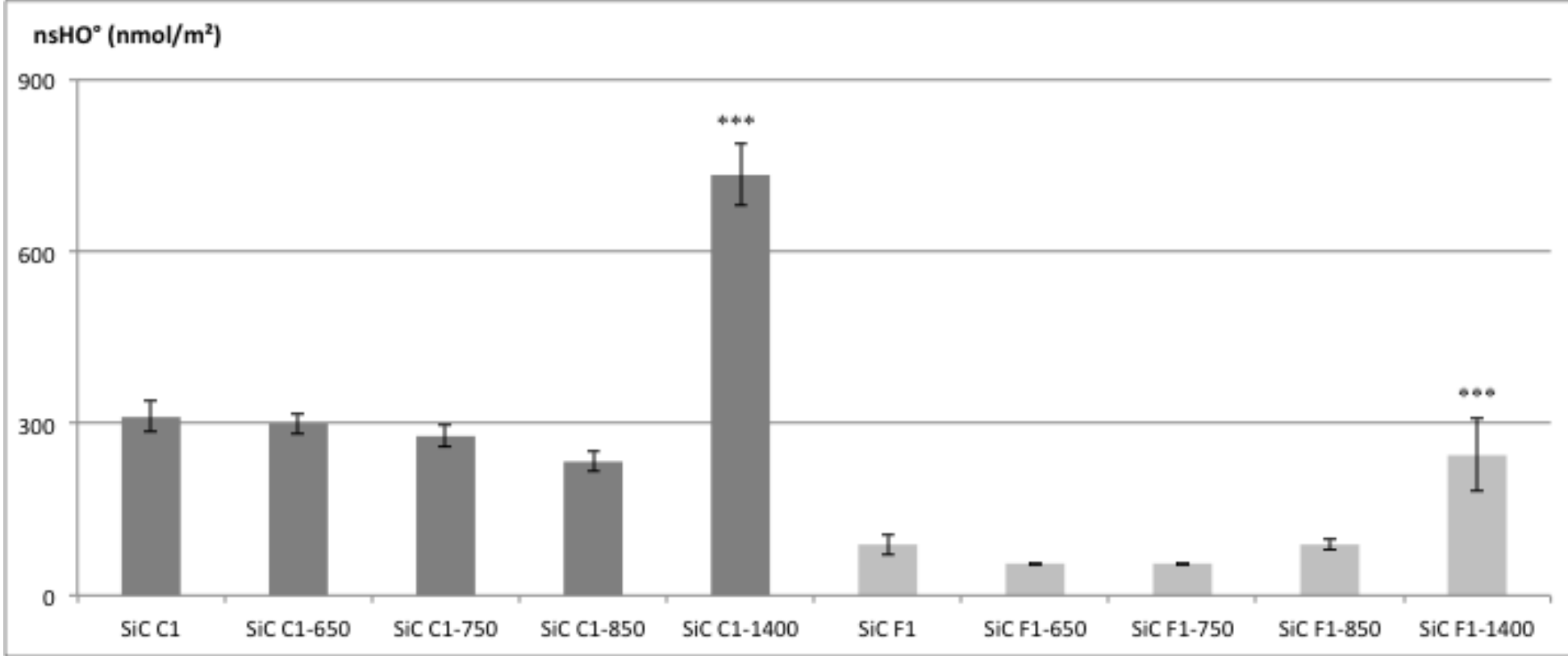

B

$\mathrm{nsCOO}{ }^{\circ}-\left(\mathrm{nmol} / \mathrm{m}^{2}\right)$

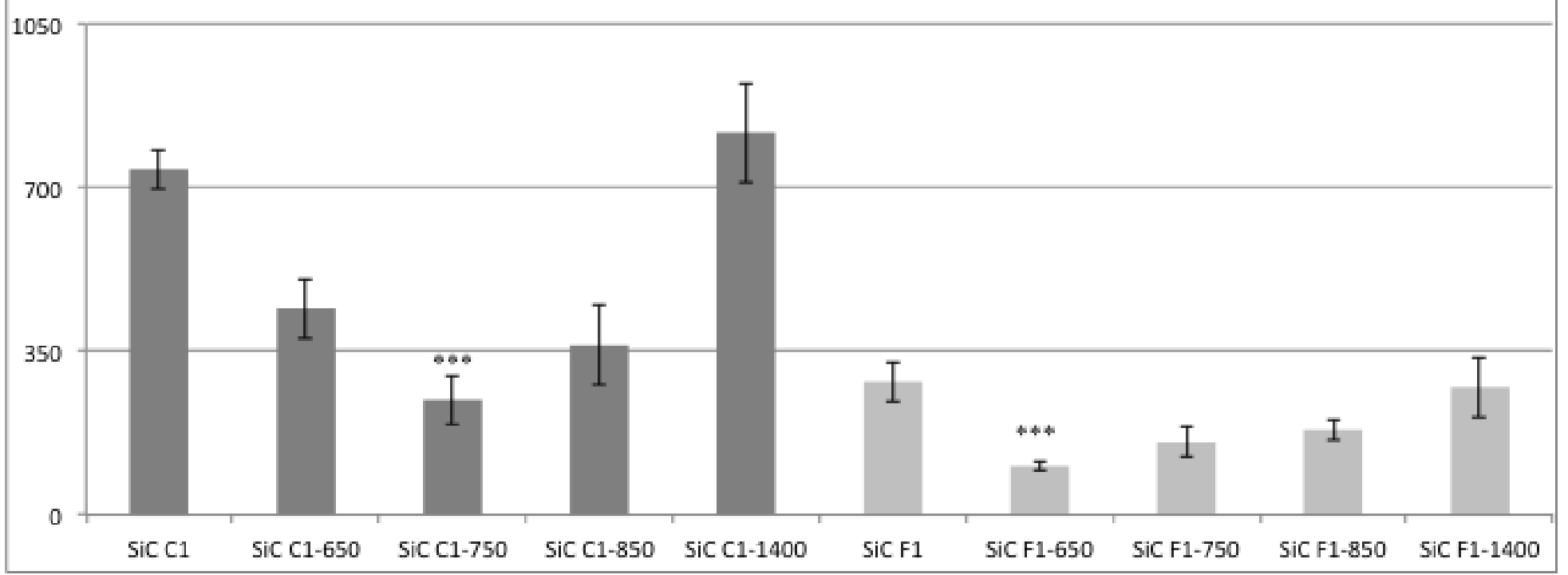


Table 1 - Physico-chemical characteristics of different SiC microparticles

\begin{tabular}{|c|c|c|c|c|c|c|c|c|}
\hline Sample & $\begin{array}{c}\text { SSA } \\
\left(\mathbf{m}^{2} / \mathbf{g}\right)\end{array}$ & $\begin{array}{c}\text { Median } \\
\text { diameter } \\
\mathrm{D}_{50}(\mu \mathrm{m})\end{array}$ & $\begin{array}{c}\text { Cristallite } \\
\text { phases }\end{array}$ & $\begin{array}{l}\text { O1s (\% } \\
\text { atomic) }\end{array}$ & $\begin{array}{c}\text { C/Si } \\
\text { (atomic } \\
\text { ratio) }\end{array}$ & $\begin{array}{c}\mathbf{F e} \\
(\mathbf{p p m})\end{array}$ & $\begin{array}{c}\text { Al } \\
(\mathbf{p p m})\end{array}$ & Schematic representation \\
\hline $\mathrm{SiC} \mathrm{C1}$ & 4.0 & 2,5 & $\begin{array}{l}\text { SiC-6H }(91 \%) \\
\text { SiC-4H }(7 \%) \\
\text { SiC-15R }(<1 \%)\end{array}$ & $\begin{array}{c}17 \\
\text { (presence } \\
\text { of a } \mathrm{SiO}_{2} \\
\text { layer) }\end{array}$ & 0,98 & 2370 & 350 & $\mathrm{Fe}$ \\
\hline $\mathrm{SiC} \mathrm{F1}$ & 11.0 & 0,5 & $\begin{array}{l}\text { SiC-6H (91\%) } \\
\text { SiC-4H (7\%) } \\
\text { SiC-15R }(2 \%)\end{array}$ & $\begin{array}{c}22 \\
\text { (presence } \\
\text { of a } \mathrm{SiO}_{2} \\
\text { layer) }\end{array}$ & 1 & 1570 & 560 & $\begin{array}{l}\mathrm{Fe} \\
\mathrm{Al} \\
\mathrm{Fe} \text { Si@ }\end{array}$ \\
\hline $\mathrm{SiC} \mathrm{I}$ & 3.0 & 6 & $\begin{array}{c}\mathrm{SiC}-6 \mathrm{H}(53 \%) \\
\mathrm{SiC}-4 \mathrm{H}(7 \%) \\
\mathrm{SiC}-15 \mathrm{R}(5 \%) \\
\mathrm{SiO}_{2} \text { quartz } \\
(9 \%) \\
\mathrm{SiO}_{2} \\
\text { cristobalite } \\
(5 \%)\end{array}$ & $\begin{array}{c}23 \\
\text { (presence } \\
\text { of a } \mathrm{SiO}_{2} \\
\text { layer) }\end{array}$ & 1,66 & 20000 & 1300 & $\begin{array}{l}\mathrm{Fe} \\
-\mathrm{Fe} \\
\mathrm{Fe} \\
\mathrm{Fe} \\
\mathrm{Fe} \\
\mathrm{SiO}^{2}\end{array}$ \\
\hline $\mathrm{SiC} \mathrm{C} 2$ & 3.5 & 2,5 & $\begin{array}{l}\text { SiC-6H (90\%) } \\
\text { SiC-4H (7\%) } \\
\text { SiC-15R }(2 \%)\end{array}$ & $\begin{array}{c}17 \\
\text { (presence } \\
\text { of a } \mathrm{SiO}_{2} \\
\text { layer) }\end{array}$ & 0,99 & 2230 & 730 & $\mathrm{Fe}_{\mathrm{Fe}}^{\mathrm{Fe}} \underbrace{\mathrm{Al}}_{\mathrm{SiO}} \mathrm{Fe}$ \\
\hline $\mathrm{SiC} \mathrm{F2}$ & 8.5 & 0,8 & $\begin{array}{l}\text { SiC-6H (90\%) } \\
\text { SiC-4H (3\%) } \\
\text { SiC-15R (7\%) }\end{array}$ & $\begin{array}{c}23 \\
\text { (presence } \\
\text { of a } \mathrm{SiO}_{2} \\
\text { layer) }\end{array}$ & 0,98 & 1370 & 0 & $\begin{array}{l}\mathrm{Fe} \\
\mathrm{Si} \\
\mathrm{Fe}\end{array}$ \\
\hline
\end{tabular}

